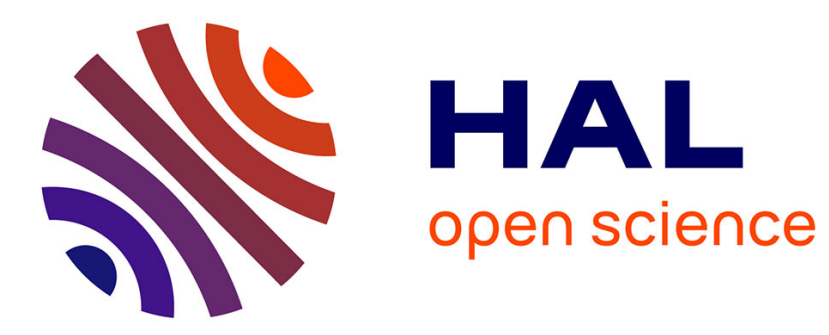

\title{
Biology and ecology of the Flavescence dorée vector Scaphoideus titanus: a review
}

Julien Chuche, Denis Thiéry

\section{To cite this version:}

Julien Chuche, Denis Thiéry. Biology and ecology of the Flavescence dorée vector Scaphoideus titanus: a review. Agronomy for Sustainable Development, 2014, 34 (2), pp.381-403. 10.1007/s13593-0140208-7 . hal-01234829

\author{
HAL Id: hal-01234829 \\ https://hal.science/hal-01234829
}

Submitted on 27 Nov 2015

HAL is a multi-disciplinary open access archive for the deposit and dissemination of scientific research documents, whether they are published or not. The documents may come from teaching and research institutions in France or abroad, or from public or private research centers.
L'archive ouverte pluridisciplinaire HAL, est destinée au dépôt et à la diffusion de documents scientifiques de niveau recherche, publiés ou non, émanant des établissements d'enseignement et de recherche français ou étrangers, des laboratoires publics ou privés. 


\title{
Biology and ecology of the Flavescence dorée vector Scaphoideus titanus: a review
}

\author{
Julien Chuche • Denis Thiéry
}

Accepted: 16 January 2014 / Published online: 26 February 2014

(C) INRA and Springer-Verlag France 2014

\begin{abstract}
Flavescence dorée is a serious disease for European vine growers. Indeed, Flavescence dorée causes yield losses and lower grape quality. As a consequence, Flavescence dorée is costly and needs advanced control strategies. For instance, in 2005, 34 million Euro was given to Italian vine growers to compensate losses due to the disease. The infection by Flavescence dorée results from the association of a phytoplasma and the leafhopper vector, Scaphoideus titanus. Despite mandatory controls using insecticides, Flavescence dorée is still spreading in Europe. Here, we review the biology and ecology of $S$. titanus to suggest improved management techniques. The main findings are as follows. (1) The longdistance spread of $S$. titanus is mainly due to human activities, and all European vineyards are susceptible to be colonized. (2) $S$. titanus is an efficient vector because it can reach a high population level and it is specific to Vitis spp. (3) Current control and prophylaxis are insufficiently effective. (4) Variation in vector populations and vector capacities lead to differential risks of plant infection. Factors driving such population variations could be modeled to improve $S$. titanus control. (5) Feeding behavior is a key factor in the phytoplasma-vector relationship. (6) The infection risk is mainly limited by vector control. To decrease pesticide use, a cross survey of the vector population and of the infected stocks triggers mandatory treatments. (7) Alternative sustainable methods or strategies are required to reduce insecticide use and increase control efficiency. In the short term, new models could
\end{abstract}

J. Chuche $\cdot$ D. Thiéry $(\bowtie)$

INRA, ISVV, UMR 1065 Santé et Agroécologie du Vignoble, F-33883 Villenave d'Ornon, France

e-mail: thiery@bordeaux.inra.fr

J. Chuche $\cdot$ D. Thiéry

Université de Bordeaux, ISVV, UMR 1065 Santé et Agroécologie du

Vignoble, Bordeaux Sciences Agro, 33883 Villenave d'Ornon, France support the establishment of more sustainable pest management operations. In the long term, innovative techniques involving symbionts, mating disruption and a push-pull strategy could improve S. titanus and Flavescence dorée control with less environmental impact.

Keywords Scaphoideus titanus · Grapevine · Insect · Vector · Phytoplasma $\cdot$ Leafhoppers

\section{Contents}

1. Introduction $\ldots \ldots \ldots \ldots \ldots \ldots \ldots \ldots \ldots \ldots \ldots \ldots \ldots$

2. Symptoms and impact of Flavescence dorée in viticulture $\ldots \ldots \ldots \ldots \ldots \ldots \ldots \ldots \ldots$

3. Introduction to Europe and spatial spread ......... 4

4. Biology .......................... 6

4.1. Life cycle . . . . . . . . . . . . . . . 6 4.1.1. Egg diapause outlet and cold requirements . .7

4.1.2. Nymphal instars . . . . . . . . . . . 8

4.1.3. Adult mating behavior . ...........8

4.2. Host range and population levels: the probability for the vector to feed on a host . . . . . . . . . 9

4.3. Population biology: the vector density ........10

5. Relationships with phytoplasma: the vector competence........................11

5.1. Feeding behavior and vectorial capacity .......11

5.2. Interactions between S. titanus and the phytoplasma causing Flavescence dorée: the longevity of vector life after IP . . . . . . . . . . . . . . . . . .11

6. Vector management: current options ............12

6.1. Vector control .....................12 6.2. Use of healthy planting material ..........13 
6.3. The removal or control of Flavescence dorée and S. titanus reservoirs ......................14

6.4. Reducing the probability of vector survival by biological control agents . . . . . . . . . . . . . . 14

6.5. Vector monitoring . . . . . . . . . . . . . 14

7. Future directions for research and management.....15

7.1. Vector control .........................15

7.2. Breaking the phytoplasma cycle ...........16

7.3. Integrated vector management ...........17

8. Acknowledgments . . . . . . . . . . . . . . . 17

9. References ...............................17

\section{Introduction}

There are major concerns that pathogen transmission by animal vectors may cause major epidemics either in humans or in agronomic products (Lemon et al. 2008). Currently, most vector-borne epidemics are managed through vector control. In agricultural insect-borne epidemics, the alternative control to insecticides is the development of integrated pest management techniques or integrated vector management. Among these epidemics, phytoplasma-borne diseases are concerning. Phytoplasmas are wall-less bacterial pathogens, persistently transmitted in a propagative manner, that are responsible for hundreds of plant diseases worldwide (Lee et al. 2000; Bertaccini and Duduk 2009; Strauss 2009). In 2001, apple production alone suffered $€ 25$ million losses in Germany and $€ 100$ million in Italy (Strauss 2009) due to phytoplasma-borne diseases. The only currently available control approach for these diseases focuses on the vector since controlling the phytoplasma is not yet possible.

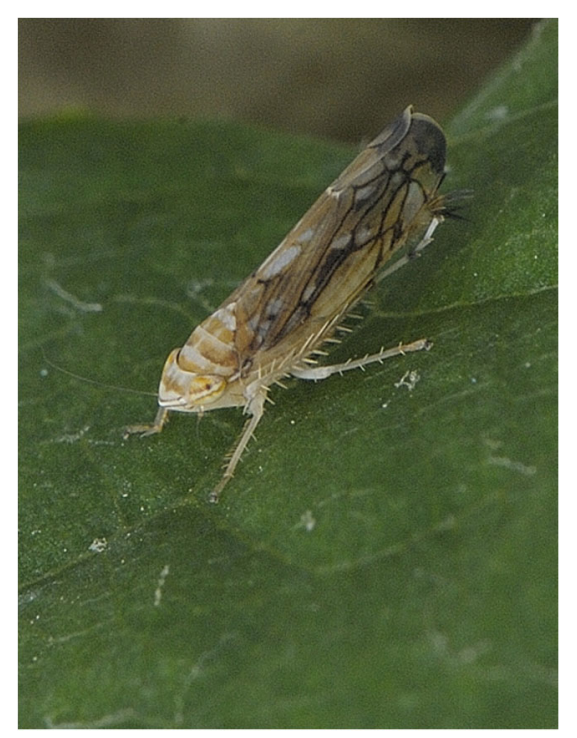

Fig. 1 Scaphoideus titanus adult on a grapevine leaf
Currently, European viticulture is being confronted with two serious phytoplasma-borne diseases, Flavescence dorée and bois noir, with Flavescence dorée being caused by phytoplasma strains of the elm yellows group (16SrV) (Angelini et al. 2003) and Bois noir by "Candidatus Phytoplasma solani”" (16SrXII) (Quaglino et al. 2013). Interestingly, the Flavescence dorée vector is highly species specific (Schvester et al. 1961), while the bois noir is not. The leafhopper vector of Flavescence dorée, Scaphoideus titanus (Hemiptera: Cicadellidae), is a specialist of Vitis in Europe and is the only known vector of Flavescence dorée from one grapevine to another in the field (Fig. 1). Thus, the vectorial capacity of $S$. titanus is the main limiting factor on disease progression.

In spite of the mandatory control of S. titanus, Flavescence dorée is still spreading in Europe.

For example, 40,000 vines with Flavescence dorée were detected in 2011 on 25,000 ha surveyed in the Bordeaux area of southwestern France, producing an average ratio of 1.6 infected vine stocks per hectare. From 2008 to 2010, vineyard area under mandatory control increased by $8 \%$ in France (Trespaille-Barrau and Grosman 2011). Thus, it is necessary to improve current control techniques and to develop new control strategies. Vector age is one major trait influencing the vectorial capacity, and it could represent an interesting tool in epidemic management. Additionally, the effectiveness of other vector control strategies could be considered for $S$. titanus. As an example, controlling malaria and dengue fever has been attempted by managing the vector populations and especially the vector longevity (Cook et al. 2008).

In disease vectors, the vectorial capacity $(\mathrm{V})$ has been related to five main variables (Cook et al. 2008) and is adaptable to Flavescence dorée transmission by $S$. titanus.

$V=\frac{m a^{2} p^{n} b}{-\ln p}$

where $m$ is the vector density; $a$ the probability of the vector feeding on a host, which can be extended to all behaviors related to feeding (leaf choice, plant choice, and spatial dispersion); $p$ the probability of vector survival; $n$ the duration of the incubation period (IP); $b$ the vector competence; and $1 /(-\ln p)$ is the longevity of a vector life after IP.

A higher vectorial capacity is attained when the insect vector has a wide range of host plants, is mobile to locate new host plants and new habitats, and has sufficient longevity to optimally acquire and transmit the pathogen. Feeding behaviors, like those of sucking insects with specialized mouthparts, allow for the efficient acquisition and transmission of pathogens. In vector-borne pathogens, the rate of transmission varies depending upon the vector or pathogens' life history traits, such as population sizes or strains, and environmental ecosystem parameters, such as resource availability and distribution (main 
hosts), potential alternative hosts, natural enemies, and climatic conditions (Daugherty et al. 2010). Thus, the transmission rate of vector-borne pathogens is strongly correlated with the size and dynamics of the vector population (Jeger et al. 2004) as well as its biology and behavior.

By acting on these parameters, it is possible to affect the vectors' capacity and propose alternatives to chemical controls. With the Flavescence dorée epidemic expanding throughout European viticulture, an increasingly severe impact can be expected in the near future. It would, therefore, seem urgent to promote integrated strategies based on results from research projects involving in phytoplasma-plant interactions and those studying the vector. We review the vector research performed and examine the intimate relations between the vector, its host plant, and the phytoplasma. These intimate relations are keys to improving our understanding and control of the vector populations and, thus, the epidemic. Focusing on the insect biology, behavior and ecology, we attempt to identify gaps in the knowledge of $S$. titanus and suggest research perspectives that will improve Flavescence dorée management.

Among the different tools that may be implemented in an integrated pest management program for controlling the Flavescence dorée epidemic in vineyards, this review also identifies prospective integrated pest management components for future vector management: (1) managing the insect population's age structure; (2) developing methods targeting insect longevity; (3) affecting the host plant selection, feeding behaviour, and vector dispersion patterns based on push-pull strategies (Cook et al. 2007); and (4) that disrupt reproduction, as seen in some other agronomic pests.

\section{Symptoms and impact of Flavescence dorée in viticulture}

Flavescence doré phytoplasma, which is a quarantined organism included in the A2 EPPO list (no. 2000/297CE directive),

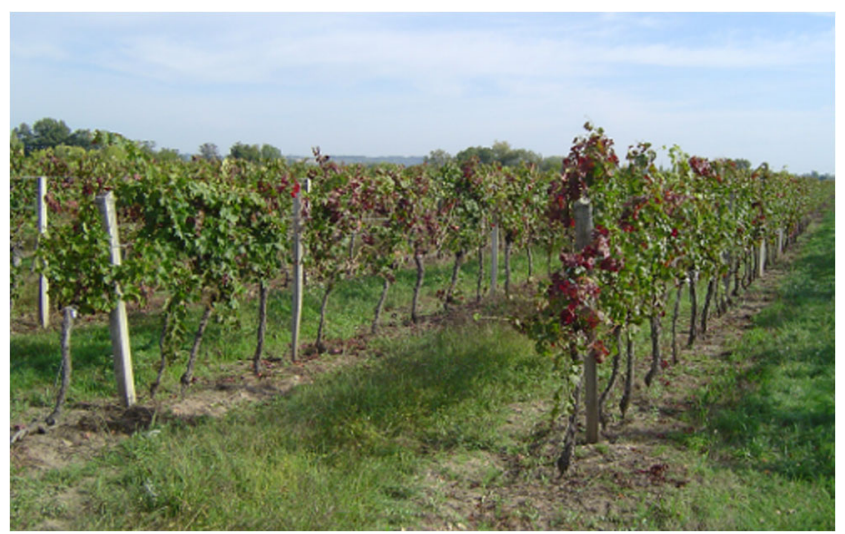

Fig. 2 Flavescence dorée symptoms in a Bordeaux vineyard. Diseased stocks have discolored and curled-down leaves. This is illustrated by the first stock in the right row

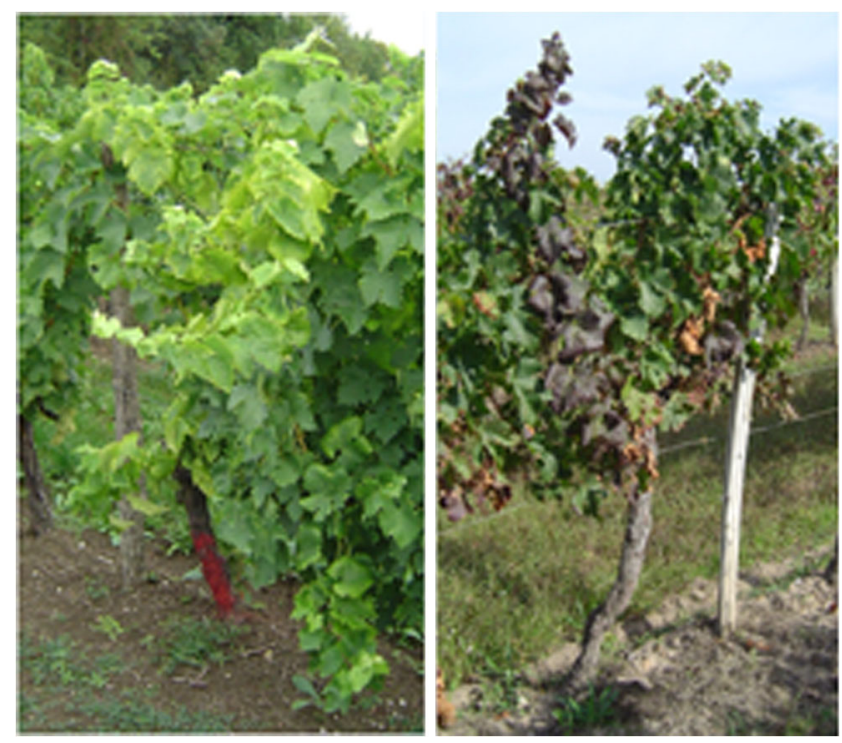

Fig. 3 Symptoms of flavescence doré. Yellowish leaves on the white cultivar Ugni blanc (on the left) and reddish leaves on the red cultivar Merlot (on the right)

is responsible for one of the most severely damaging diseases in European vineyards, with severe economic consequences in the major wine- and vine-producing countries (Fig. 2).

The first visible symptom of Flavescence dorée is either a delayed or lack of bud break on the most severely damaged vines (Caudwell 1964), with other characteristic symptoms appearing in the summer. The canes then droop because of a lack of lignification in the new shoots, with the leaves curling downwards and becoming yellowish in white cultivars or reddish in red ones (Fig. 3). Flavescence dorée also causes the death of inflorescences and berries (Caudwell 1964). By reducing photosynthesis activity and nutrient transport, which leads to decreased grape quality, the phytoplasma can also cause a $50 \%$ reduction in yields (Credi 1989). At this point, plants can either die or recover, but they continue to be less productive (Credi 1989; Boudon-Padieu 2000).

In Switzerland, where Flavescence dorée was only found in Ticino (representing $7 \%$ of all Swiss vineyards), the two mandatory buprofezin treatments cost $€ 250,000$ alone (Jermini, 2013, personal communication). In Serbia, primary economic losses due to vineyard destruction in the Aleksandrovac region were estimated at approximately $€ 3.2$ million in 2005 (Steffek et al. 2007). Flavescence dorée costs to growers include yield losses, vector control strategies, removing symptomatic grapevines, and low productivity of replacement plants. The control of Flavescence dorée also has an impact on the overall economy. For example, in Piedmont (northwest Italy), the regional administration spent approximately $€ 1.5$ million per year between 1999 and 2003 in disease control programs, while in 2005 , the Italian government and the European Union compensated the growers with $€ 34$ million for yield losses and replanting (Belli et al. 2010). The cost of replacing symptomatic plants varies considerably 
according to the cultivar, vineyard management, the yield, and age of the vineyard. In northeast Italy, the average annual cost of replacement was estimated at $€ 0.28$ per plant for a 25 -yearold productive vineyard planted with "Merlot" at 3,000 plants ha ${ }^{-1}$ with an $8 \mathrm{t} \mathrm{ha}^{-1}$ grape yield, and at $€ 6.50$ for a 5year-old productive vineyard planted with "Perera" at 1,500 plants ha ${ }^{-1}$ with a $13 \mathrm{t} \mathrm{ha}^{-1}$ yield (Pavan et al. 2012).

\section{Introduction to Europe and spatial spread}

The introduction of $S$. titanus to Europe is now almost fully understood. It was first observed in France in 1958 (Bonfils and Schvester 1960), is attributed to human intervention, and originated in North America, probably in the northeastern region (Papura et al. 2012). A survey program conducted over the three following years recorded only low populations throughout southwest France (Bonfils and Schvester 1960). An inventory of the French Jassidae (now known as Cicadellidae) performed in 1927 did not mention S. titanus (Ribaut 1952). Thus, its introduction may have occurred between these two events. However, in the early 1960s, $S$. titanus individuals were discovered in other French and foreign vineyards, such as Charente Maritime, Haute Garonne, Hérault, Alpes Maritimes, Var, Vaucluse, and northwestern Italy (Schvester et al. 1962b; Vidano 1964), which calls into question the starting date of the vector's biological invasion. However, S. titanus may have already been present in 1927, but at such a small spatial scale and population level that it was not recorded in the Ribaut's inventories. The insect dissemination then extended to most French and European vineyards and is now found from west to east, from Portugal to Romania, and from north to south, from Champagne in France to Basilicata in Italy (Fig. 4; Table 1).
An important event in French viticulture, the Phylloxera crisis, occurred more than a century ago and was resolved by completely replanting the French vineyards (more than 800,000 ha) with new grapes grafted on American rootstocks (Granett et al. 2001). The importation of large amounts of American rootstocks occurred, and they were intensely multiplied in several nurseries, especially in southwestern France (Carton et al. 2007). Thus, the introduction of this insect at this time is a feasible hypothesis.

Population genetics studies reveal a much smaller genetic diversity in European S. titanus populations than in American populations, indicating that the former originated from a single introduction (Bertin et al. 2007; Papura et al. 2007, 2009, 2012), although an unusually high-frequency mitochondrial haplotype is present in Switzerland, suggesting at least one other introduction (Papura et al. 2012). The spread of the vector in Europe is based mainly on the dispersion of introduced populations rather than on multiple introductions (Pavan et al. 1997; Bertin et al. 2007; Papura et al. 2009). This dispersion also appears linked to human activities. The hypothesis that population dispersal is related to trading vine cuttings for planting (Bertin et al. 2007; Papura et al. 2009) is consistent with the low adult dispersal ability of $S$. titanus, which is estimated to be a distance of $25-30 \mathrm{~m}$ in the vineyards (Lessio and Alma 2004a; Beanland et al. 2006), and the role of roads in the spread of exotic species (Trombulak and Frissell 2000). Evidence for the longdistance dispersal of vector and phytoplasma by infested planting material is provided by the widespread distribution of the Flavescence doré-2 strain, which has a high clonality level, in both France and Italy (Arnaud et al. 2007).

The small-scale dispersion ability of $S$. titanus does not exclude the larger scale passive dissemination of infectious S. titanus over longer distances by the wind, as is the case for aphids and fig wasps (Compton 2002). Initial observations on
Fig. 4 Distribution of Scaphoideus titanus among European vineyards

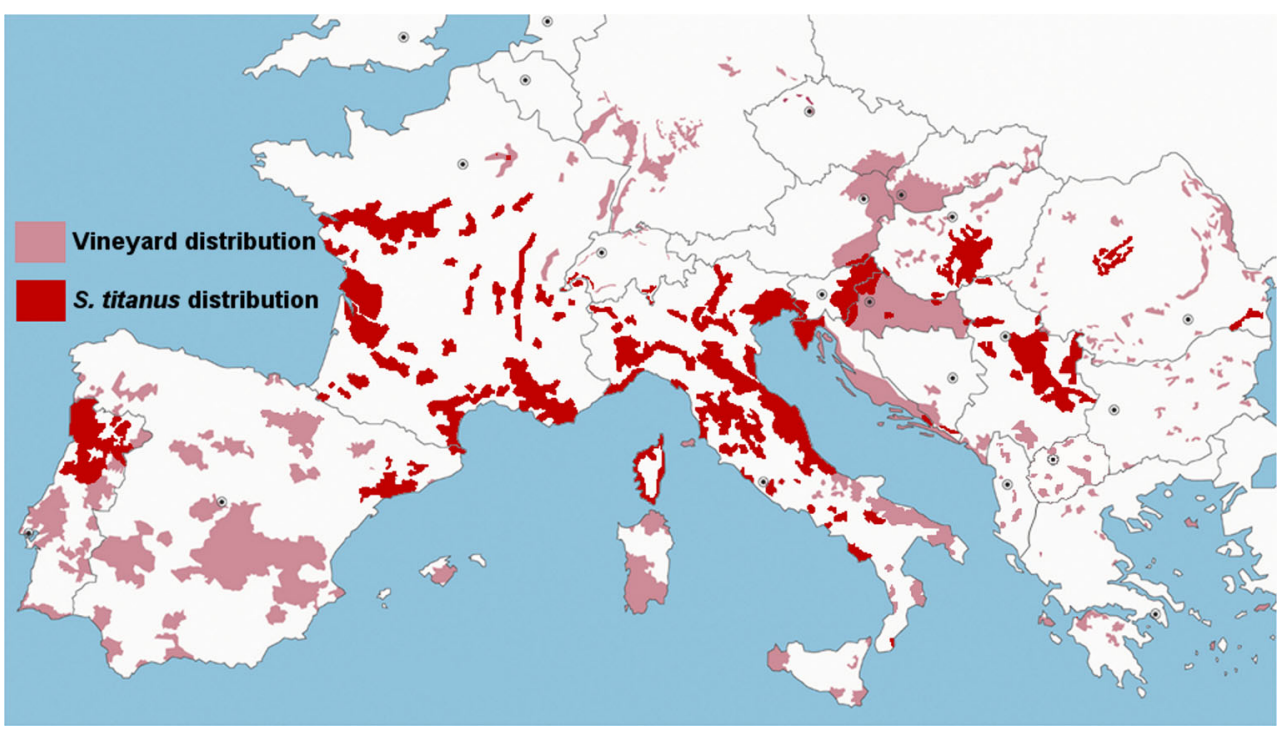


Table 1 European viticultural areas where S. titanus was recorded

\begin{tabular}{|c|c|c|c|}
\hline Country & Region & First record & References \\
\hline Austria & Southern Styria & 2004 & (Steffek et al. 2007) \\
\hline Bosnia-Herzegovina & Trebinje (South) & 2007 & (Delic et al. 2007) \\
\hline Bulgaria & North & 2006 & (Avramov et al. 2011) \\
\hline Croatia & All regions & 2003 & (Budinščak et al. 2005) \\
\hline \multirow[t]{27}{*}{ France } & Alpes Maritimes & 1961 & (Schvester et al. 1962b) \\
\hline & Ardèche & 1986 & (Caudwell and Larrue 1986) \\
\hline & Aude & & (Vidano 1964) \\
\hline & Bouches du Rhône & 1985 & (Caudwell and Larrue 1986) \\
\hline & Bourgogne & & (Boudon-Padieu 2000) \\
\hline & Champagne-Ardennes & 2011 & (DRAAF-SRAL and CIVC 2012) \\
\hline & Charente & & (Caudwell et al. 1974) \\
\hline & Charentes & 1961 & (Schvester et al. 1962b) \\
\hline & Corsica & 1971 & (Boubals and Caudwell 1971) \\
\hline & Côtes du Rhône & & (Caudwell et al. 1974) \\
\hline & Dordogne & & (Caudwell and Larrue 1986) \\
\hline & Drôme & & (Caudwell and Larrue 1986) \\
\hline & Gard & 1986 & (Caudwell and Larrue 1986) \\
\hline & Gers & & (Bonfils and Schvester 1960) \\
\hline & Gironde & 1958 & (Bonfils and Schvester 1960) \\
\hline & Haute Garonne & & (Vidano 1964) \\
\hline & Hautes et Basses Pyrénées & & (Bonfils and Schvester 1960) \\
\hline & Hérault & 1961 & (Schvester et al. 1962b) \\
\hline & Landes & & (Bonfils and Schvester 1960) \\
\hline & Languedoc & & (Caudwell et al. 1974) \\
\hline & Midi-Pyrénées & & (Caudwell et al. 1974) \\
\hline & Poitou & & (Della Giustina 1989) \\
\hline & Savoie & 1986 & (Della Giustina 1989) \\
\hline & Sud-Beaujolais & 1987 & (Della Giustina 1989) \\
\hline & Var & & (Vidano 1964) \\
\hline & Vaucluse & & (Vidano 1964) \\
\hline & Yonne & 1998 & (Boudon-Padieu 2000) \\
\hline \multirow[t]{2}{*}{ Hungary } & South West & & (Der et al. 2007) \\
\hline & East & & (Orosz and Zsolnai 2010) \\
\hline \multirow[t]{15}{*}{ Italy } & Abruzzo & 2001 & (Belli et al. 2010) \\
\hline & Basilicata & 2002 & (Viggiani 2002) \\
\hline & Campania & 2004 & (Danise et al. 2005) \\
\hline & Emilia-Romagna & 1987 & (Cravedi et al. 1993) \\
\hline & Friuli-Venezia Giulia & 1986 & (Belli et al. 2010) \\
\hline & Liguria & 1964 & (Vidano 1964) \\
\hline & Latium & 2005 & (Bagnoli et al. 2008) \\
\hline & Lombardy & 1975 & (Osler et al. 1975) \\
\hline & Marche & 2001 & (Belli et al. 2010) \\
\hline & Umbria & 2002 & (Santinelli et al. 2003) \\
\hline & Piedmont & 1988 & (Vidano et al. 1988) \\
\hline & Tuscany & 1998 & (Santini and Lucchi 1998) \\
\hline & Trentino-Alto Adige & 1990 & (Belli et al. 2010) \\
\hline & Valle d'Aosta & 2006 & (Belli et al. 2010) \\
\hline & Veneto & 1983 & (Belli et al. 1985) \\
\hline \multirow[t]{2}{*}{ Portugal } & North & 1998 & (Quartau et al. 2001) \\
\hline & Centre & & (de Sousa et al. 2010) \\
\hline
\end{tabular}


Table 1 (continued)

\begin{tabular}{llll}
\hline Country & Region & First record & References \\
\hline \multirow{3}{*}{ Romania } & Madeira & 2010 & (de Sousa et al. 2010) \\
& Transylvania (Blaj) & 2009 & (Chireceanu et al. 2011) \\
& Bucharest area & 2009 & (Chireceanu et al. 2011) \\
Serbia & Constanța County (Murfatlar) & 2009 & (Chireceanu et al. 2011) \\
& Centre and South & & (Magud and Tosevski 2004) \\
& South & & (Duduk et al. 2004) \\
Slovenia & All regions, except Pčinja & & (Krnjajic et al. 2007) \\
& West & & (Seljak 1987) \\
Spain & South West & 1983 & (Seljak 1987) \\
Switzerland & All regions & & (Seljak 2008) \\
& Catalonia & & (Rahola et al. 1997) \\
& Romandie, Geneva area & 1996 & (Clerc et al. 1997) \\
& Ticino & 1968 & (Baggiolini et al. 1968) \\
& Vaud and Geneva & 2006 & (Schaerer et al. 2007) \\
\hline
\end{tabular}

Flavescence dorée showed that secondary outbreaks were related to the wind (Caudwell 1957), suggesting the aerial dispersal of the vector. This hypothesis, which seems relevant, was used to explain the spread of $S$. titanus from Slovenia to Austria. Insects were found several kilometers from infested sites, and the captures were downwind in grapevine-free areas (Steffek et al. 2007). In Spain, the spatial distribution of Flavescence dorée in Catalonia suggests the influence of the tramontane (strong north to south wind) (Rahola et al. 1997).

The spread of $S$. titanus in Europe has probably not yet ended. Several forecasting studies have found that populations of $S$. titanus could become established in certain wine regions of northern Europe, and even China because of favorable prevailing climatic conditions (Maixner 2005; Ge and Wen 2006; Steffek et al. 2007). Climate is certainly not the only factor effecting $S$. titanus' distribution since it has been recorded under different climatic conditions in many places in Canada and the USA (Fig. 5; Table 2). However, these observations should be accepted with caution because the number of morphologically similar Scaphoideus species present in North America makes them difficult to identify (Malausa et al. 2003). In addition, the morphological characteristics used for $S$. titanus identification, especially for males, show a high level of intraspecific variability and some may be similar to those of other Scaphoideus species (Barnett 1976). It should also be noted that these observations were made mostly before 1950 (Table 2), and the genus has been revised several times since then. Thus, in the revision of the genus Scaphoideus by Barnett, the species S. cyprius, S. littoralis, $S$. amplus, S. brevidens, $S$. diutius, $S$. nigrellus, $S$. scelestus, and $S$. aduncus are now known as $S$. titanus (1976). Lastly, this insect has rarely been studied in its native area, where it does not constitute an economic problem.
The long distance spread of $S$. titanus is mainly due to human activities and all European vineyards are susceptible to be colonized by this insect, which carries Flavescence dorée.

\section{Biology}

\subsection{Life cycle}

Eggs are laid in the late summer, from August through September, inside the excoriated bark of wood vines, either

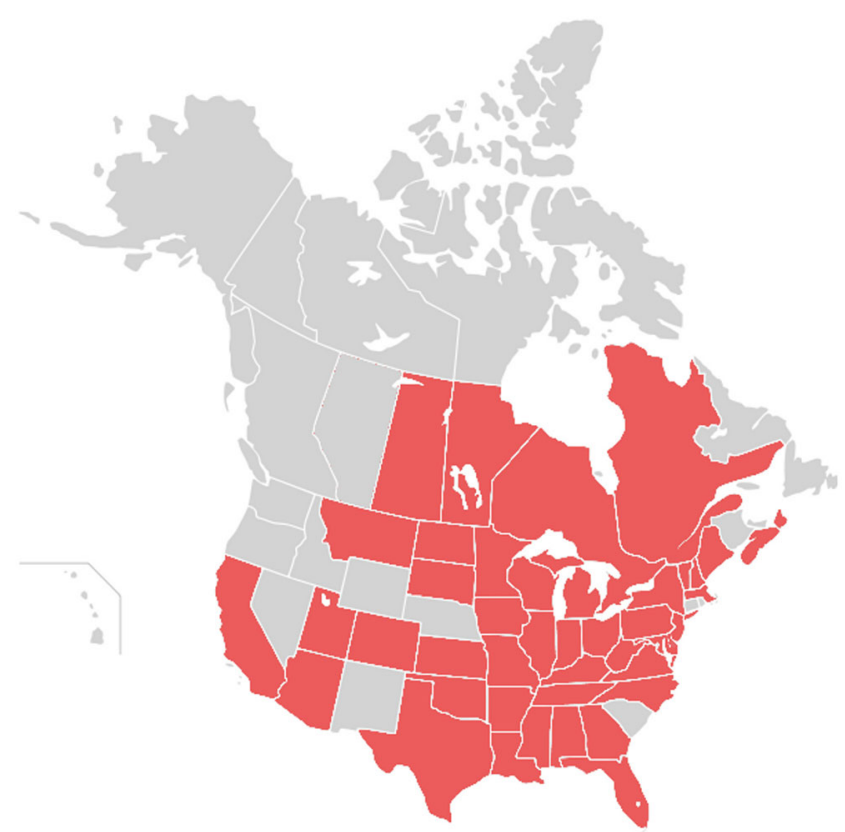

Fig. 5 States in the USA and Provinces in Canada where Scaphoideus titanus was observed 
Table 2 North American regions where S. titanus was recorded

\begin{tabular}{|c|c|c|c|}
\hline Country & State/province & First description & References \\
\hline \multirow[t]{41}{*}{ USA } & Alabama & & Barnett 1976 \\
\hline & Arizona & & Barnett 1976 \\
\hline & Arkansas & & Barnett 1976 \\
\hline & California & & Barnett 1976 \\
\hline & North Carolina & & Barnett 1976 \\
\hline & Colorado & & Barnett 1976 \\
\hline & North Dakota & & Barnett 1976 \\
\hline & South Dakota & 1946 & Metcalf 1967 \\
\hline & Delaware & & Barnett 1976 \\
\hline & Florida & & Barnett 1976 \\
\hline & Georgia & 1955 & Metcalf 1967 \\
\hline & Illinois & 1946 & Delong 1948 \\
\hline & Indiana & & Barnett 1976 \\
\hline & Iowa & & Barnett 1976 \\
\hline & Kansas & & Barnett 1976 \\
\hline & Kentucky & & Barnett 1976 \\
\hline & Louisiana & 1936 & Metcalf 1967 \\
\hline & Maine & & Barnett 1976 \\
\hline & Maryland & & Barnett 1976 \\
\hline & Massachusetts & 1932 & Metcalf 1967 \\
\hline & Michigan & & $\begin{array}{l}\text { Vidano 1966; } \\
\text { Barnett } 1976\end{array}$ \\
\hline & Minnesota & 1943 & Metcalf 1967 \\
\hline & Mississippi & & Barnett 1976 \\
\hline & Missouri & & Barnett 1976 \\
\hline & Montana & & Barnett 1976 \\
\hline & New Hampshire & & Barnett 1976 \\
\hline & New Jersey & & Barnett 1976 \\
\hline & New York & & Maixner et al. 1993 \\
\hline & Ohio & 1936 & $\begin{array}{l}\text { Osborn and } \\
\text { Knull } 1946\end{array}$ \\
\hline & Oklahoma & & Barnett 1976 \\
\hline & Pennsylvania & 1936 & Metcalf 1967 \\
\hline & Tennessee & 1936 & Metcalf 1967 \\
\hline & Texas & & Barnett 1976 \\
\hline & Utah & & Barnett 1976 \\
\hline & Vermont & & Barnett 1976 \\
\hline & Virginia & & Beanland et al. 2006 \\
\hline & West Virginia & & Hamilton 1983 \\
\hline & Wisconsin & 1936 & Metcalf 1967 \\
\hline & Eastern States & 1948 & Delong 1948 \\
\hline & South Eastern States & 1949 & Metcalf 1967 \\
\hline & Central States & 1949 & Metcalf 1967 \\
\hline \multirow[t]{5}{*}{ Canada } & Manitoba & & Maw et al. 2000 \\
\hline & Nova Scotia & & Maw et al. 2000 \\
\hline & Ontario & 1956 & Beirne 1956 \\
\hline & Québec & 1956 & Beirne 1956 \\
\hline & Saskatchewan & & Maw et al. 2000 \\
\hline
\end{tabular}

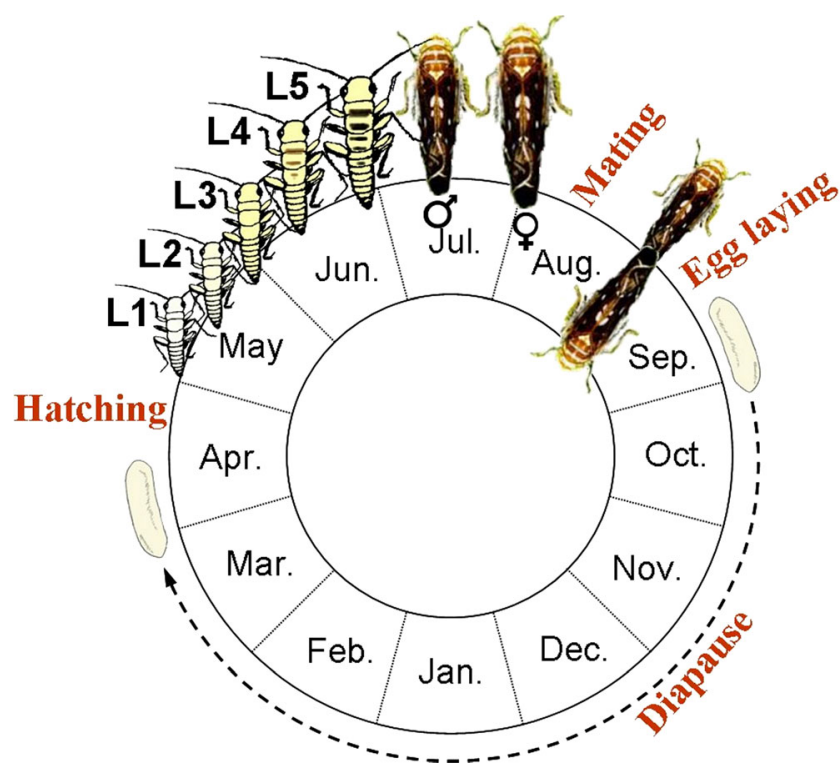

Fig. 6 Life cycle of Scaphoideus titanus. Dates are indicative and vary depending on year and location

individually or in groups (Schvester et al. 1962b; Vidano 1964; Bagnoli and Gargani 2011). Eggs have also been observed uncommonly on 1-year-old canes (Bagnoli and Gargani 2011). The fecundity of females is estimated at 10 15 eggs on average, but can reach up to 20 eggs (Vidano 1964; Cravedi et al. 1993; Bosio and Rossi 2001; Linder and Jermini 2007; Eriksson et al. 2012). One should note that this range was established using female dissections and bark examination. Therefore, such fecundity comparisons in the literature include a certain number of inaccuracies, such as the number of eggs lost during bark dissection, the number of females that oviposited, the female status when dissected, and possible egg resorption. In our opinion, the range indicated in the literature is probably underestimated. Since fecundity and fertility are key points for reproductive success and thus vector population size, an accurate evaluation is essential.

\subsubsection{Egg diapause outlet and cold requirements}

Eggs pass the winter during a 6- to 8-month diapause stage (Fig. 6), and diapause does not require the exposure to cold temperatures to be broken (Chuche and Thiéry 2012). Hatching dynamics appear to vary a great deal according to vineyard latitude, altitude, and year. In France, hatching begins about 2 weeks earlier in Corsica than in Armagnac. It is also extended over time (Caudwell et al. 1974), more than 3 months in the former region compared with 1.5 months in the latter region (Caudwell and Larrue 1986). Such extensive hatching periods are characteristic of vineyards with mild winters, as in Corsica (Boubals and Caudwell 1971), where all stages of development (first instar to adult) can occur simultaneously. In Friuli-Venezia Giulia, hatchings begin in 


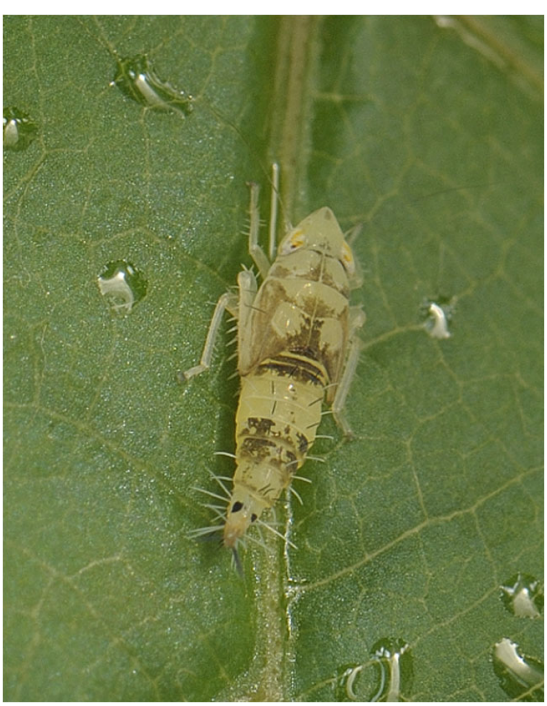

Fig. 7 Fifth nymphal instar of Scaphoideus titanus on a grapevine leaf

mid-May, but occur a few days earlier in the lower altitude than in the elevated vineyards, and the first nymphal instar can be found as late as the end of July or middle of August, depending on the year (Frausin 2000). These field data are perfectly matched by recent laboratory results showing that incubation temperatures regulate the beginning and length of the hatching dynamic. Cooling temperatures mainly affect the onset of hatching and are negatively correlated to cold exposure times. Most hatchings occur more quickly in cold rather than in mild winter conditions. In line with the Northern American origin of the vector, the diapause termination and, consequently, the timing regulation of egg hatching, requires cold winters (Chuche and Thiéry 2009; Chuche 2010). Females are more sensitive to incubation temperature variations. The different responses of males and females have consequences on the sex ratio dynamics of hatchings with less protandry after warm incubation temperatures (Chuche and Thiéry 2012).

\subsubsection{Nymphal instars}

Five nymphal instars (Figs. 6 and 7) lead to adults in 7 8 weeks in France (Vidano 1964; Boudon-Padieu 2000), while this period is shorter, 5-7 weeks, in Spain (Rahola et al. 1997) and Italy (Vidano 1964). In addition to climatic conditions, additional factors probably govern larval growth speed, but they are poorly understood. Mortality is high between the first successive instars, $50 \%$ between the first and second and between the second and third (Bernard and Du Fretay 1988). The first adults usually appear in summer, June, and July, and their lifetime is about 1 month, with females starting to lay eggs approximately 10 days after emergence (Schvester et al. 1962b). Even though S. titanus is univoltine, in 1987, the first nymphal instar was observed early in August in southern France. This was approximately 3 weeks after the last observation in mid-July of new-born nymphs, which was confirmed by a similar observation for adult caged populations (Bernard and Du Fretay 1988). This interestingly suggests that $S$. titanus could produce a second generation under certain conditions, with females from the first generation producing non-diapausing eggs (Bernard et al. 1988). To our knowledge, this has not been observed another time in the field or in the laboratory. Even though the authors did not determine whether the eggs produced by a second generation underwent diapause, their results indicate the existence of a second generation in this very specific case. However, it seems very unlikely that individuals from this second generation have time to develop into adults.

Insect voltinism can undergo gradual shifts with the occurrence of partial generations in particular regions (Välimäki et al. 2008, 2013). The phenotypic plasticity in diapause induction, according to the environmental conditions, leads some species to stop their development in diapause or to produce an additional generation. As an example, the butterfly Polygonia c-album (Lepidoptera: Nymphalidae) is univoltine in Sweden, even though a partial second generation can occur in the southern region and a shift from one to two generations of Swedish populations is soon expected (Audusseau et al. 2013). In the same way, the planthopper Hyalesthes obsoletus (Hemiptera: Cixiidae), which is the vector of the phytoplasma disease bois noir in vineyards, is strictly monovoltin in Europe but is bivoltin in Israel (Sharon et al. 2005). The occurrence of a second generation should be investigated since multivoltinism is an evolutionary key in population increases, the adaptation and distribution of insects, and would have potential consequences on $S$. titanus spreading southwardly (Logan et al. 2003; Dalin 2011; Jonsson et al. 2011; Stoeckli et al. 2012).

Nymphs usually remain on the plant where they hatch (Maixner et al. 1993). However, their mobility allows them to easily travel from plant to plant. Young nymphs feed preferentially on suckers when they are not removed (Schvester et al. 1962b; Bernard and Du Fretay 1988; Posenato et al. 2001). All instars prefer the more sheltered lower and inner leaves, and even in favorable weather conditions, larvae can also be located at the apex (Bernard and Du Fretay 1988).

\subsubsection{Adult mating behavior}

Mating among the Auchenorrhyncha, except for Cicadas, involves vibratory communication by signals transmitted via the plant (Čokl and Virant-Doberlet 2003). Males can emit calling signals within $24 \mathrm{~h}$ of emergence, while the earliest age of maturity in females is 6 days (Mazzoni et al. 2009b). At dusk, male $S$. titanus spontaneously emits a species-specific calling signal, thereby initiating a response from a receptive female (Mazzoni et al. 2009c). If the female responds, a mating duet will be established, with specific courtship vibratory signals being produced by the male (Mazzoni et al. 
2009c). Mating lasts from 40 to $70 \mathrm{~min}$ and, while the males can mate several times, females only mate once (Lucchi et al. 2004; Mazzoni et al. 2009c). Mating disruption, competition, and opportunism can be observed. For example, a male close to a communicating male or female can disrupt the communication of the former and/or can silently approach the receptive female to mate with her (Mazzoni et al. 2009c). The substrate-borne vibrational signal can be transmitted from two neighboring plants, through the air beyond the boundary layer of the leaves (Eriksson et al. 2011). This facilitates longdistance communication in dense habitats such as vineyards, but the propagation, which depends on the distance between leaves, will vary with the vineyard architecture.

\subsection{Host range and population levels: the probability} for the vector to feed on a host

S. titanus is mainly recorded on Vitis vinifera in Europe, while in North America, Vitis labrusca and Vitis riparia are reported as the preferred host plants (Vidano 1964; Maixner et al. 1993). In its native area, most individuals were found in the woods or hedges where these two wild grape species are present, while only a few individuals were observed in vineyards (Vidano 1966; Maixner et al. 1993; Beanland et al. 2006). Interestingly, this preference for American Vitis rather than $V$. vinifera is also observed in Europe where both species coexist (Lessio et al. 2007). However, the species of Vitis were not identified, and insecticide treatments targeting the grapes may well have interfered with such observations. In Europe, S. titanus was also observed on $V$. labrusca and Parthenocissus quinquefolia (Table 3). It has also been observed occasionally on plants other than Vitaceae, such as Salix viminalis and Prunus persica, when growing in close vicinity to vines, and in large numbers on American elm (Ulmus americana) in the USA (Table 3). S. titanus was also recorded in North America on many additional plants whose host status has not yet been demonstrated (Table 3) and in various environments including forests, meadows, orchards, and bogs (Barnett 1976; Hill and Sinclair 2000). S. titanus, like other oligophagous species, accomplishes its whole life cycle on one genus (Vitis), but it can feed on other food plants. Studies on the survival of $S$. titanus on other plants outside the Vitis gender revealed that few species supported development to adulthood and those that did developed mainly from old nymphal instars, with a huge mortality rate (Schvester et al. 1962b; Caudwell et al. 1970; Trivellone et al. 2013). Feeding on others plants does not mean that these plants constitute host plants because no species outside of the Vitis genus has been shown to sustain the whole life cycle, from egg to egg, of $S$. titanus. However, that $S$. titanus can feed on other plants should be considered, particularly since they may act as pathogen reservoirs. The main scenario for the appearance of Flavescence dorée in vineyards implies a role for other vectors in introducing the phytoplasma to cultivated grapevines from wild plants. The leafhopper Oncopsis alni (Maixner et al. 2000; Arnaud et al. 2007) and the planthopper Dictyophara

Table 3 Plants on which $S$. titanus was recorded

\begin{tabular}{|c|c|c|c|}
\hline Familly & Species & Comments & References \\
\hline Amaranthaceae & Amaranthus sp. & Few individuals & Posenato et al. 2001 \\
\hline Apiaceae & Daucus carota & Wild grapevines and vineyards nearby & Drobnjakovic et al. 2011 \\
\hline Asteraceae & Solidago sp. & & Barnett 1976 \\
\hline Chenopodiaceae & Chenopodium sp. & Few individuals & Posenato et al. 2001 \\
\hline Convolvulaceae & Convolvulus sp. & Few individuals & Posenato et al. 2001 \\
\hline Cupressaceae & Juniperus virginiana & & Barnett 1976 \\
\hline Dryopteridaceae & Onoclea sinsibilis & & Barnett 1976 \\
\hline Fabaceae & Vicia faba & Laboratory host plant & Caudwell et al. 1970 \\
\hline Poaceae & - & & Barnett 1976 \\
\hline Polygonaceae & Polygonum sp. & & Barnett 1976 \\
\hline \multirow[t]{3}{*}{ Rosaceae } & Crataegus sp. & & Barnett 1976 \\
\hline & Prunus persica & & Barnett 1976; Schvester et al. 1962a \\
\hline & Malus sp. & & Barnett 1976 \\
\hline \multirow[t]{2}{*}{ Salicaceae } & Salix sp. & & Barnett 1976 \\
\hline & Salix viminalis & In a vineyard, few individuals & Schvester et al. 1962a \\
\hline Ulmaceae & Ulmus americana & Huge populations & Gibson 1973 \\
\hline \multirow[t]{4}{*}{ Vitaceae } & Parthenocissus quinquefolia & All instars, except eggs & Vidano 1964; Maixner et al. 1993 \\
\hline & Vitis labrusca & & Vidano 1964; Viggiani 2002 \\
\hline & Vitis riparia & Prefered to $V$. vinifera & Maixner et al. 1993 \\
\hline & Vitis vinifera & & Bonfils and Schvester 1960 \\
\hline
\end{tabular}


europaea (Filippin et al. 2009) from Alnus glutinosa (Fagales, Betulaceae) and Clematis vitalba (Ranunculales, Ranunculaceae), respectively, could have acquired Flavescence dorée phytoplasma. This should be considered in Flavescence dorée epidemiology.

This specialization of S. titanus on Vitis could explain their reduced numbers of olfactory receptors and sensory neurons per sensillum as compared with other leafhoppers (Stacconi and Romani 2012). Despite such a reduction in olfactory sensory equipment, $S$. titanus can still detect Vitis leaves and shoot odours (Mazzoni et al. 2009a), but extended electrophysiological and behavioral studies have not been conducted.

In multicultivar vineyards, it is typical to observe different S. titanus population levels on each cultivar (Schvester et al. 1962b; Posenato et al. 2001). For example, Baco 22 A, which is sensitive to Flavescence dorée, could accommodate 5-57 times more insects than the white cultivar Villard 13 Couderc, which is more tolerant to Flavescence dorée (Schvester et al. 1962b). Differences in sensitivity were also observed in Corsica where, in a vineyard planted with Malvoisie de Corse and Grenache, the disease progressed in dense patches on the first cultivar, whereas only one vine of the second cultivar was seriously affected (Boubals and Caudwell 1971). This suggests that, although the two varieties are very susceptible, the higher frequency of contamination of Malvoisie vines was due to their higher attractiveness to the vector. In addition to investigations on cultivar sensitivity to Flavescence dorée phytoplasma (Jarausch et al. 2013), we urgently need large-scale investigations on cultivar sensitivity to the vector.

\subsection{Population biology: the vector density}

In spring, following inoculation, phytoplasmas colonize the growing leaves via the phloem on which they multiply, thereby constituting a source of infection for S. titanus. However, as typical symptoms only appear in the plant in the summer following inoculation (Schvester et al. 1969), the newly infected stocks constitute an inoculum source for the spread of Flavescence dorée before the disease can be observed. As this pathogen has a high degree of specificity to its vector, and movements of the insect from one plant to another constitute the only natural transmission paths, the rate of infection in year $n$ is strongly correlated with the vector population size that occurred in year $n-1$ (Morone et al. 2007). Without any insecticide treatments, $S$. titanus populations can attain a magnitude range of 10,000 individuals per hectare (Schvester 1969). Without vector control, Flavescence dorée spreads epidemically, so that the number of infected vines can increase up to 10-fold every year and affect the entire field within a few years (EPPO/CABI 1997). In Pyrénées-Orientales (southwestern France), the area affected by Flavescence dorée abruptly increased in size by more than 300 times, from 60 ha in 1991 to 20,000 ha in 1993, in 2 years (Pueyo et al. 2008), probably because of a disease outbreak and intensifications in vineyard monitoring. In the French department of Aude, approximately $70 \%$ of vineyards were infected only 6 years after Flavescence dorée was detected (Laurent and Agulhon 1989).

In the vineyards, the aggregated distribution of adults and larvae within plots seems to be a common pattern for this species (Bosco et al. 1997; Decante and van Helden 2006; Lessio and Alma 2006), but the spatial distribution of $S$. titanus needs further investigations to be fully understood.

S. titanus is crepuscular or nocturnal, and its flight activity is greatest between late afternoon and early morning (Lessio and Alma 2004b). This activity may be related to the crepuscular low dispersal ability, since night atmospheric lift is minimal (Taylor 1974) and sexual activity is highest between 18.00 and 20.00 (Mazzoni et al. 2009c). Flight activity increases with the daily minimum temperature, with maximum captures occurring above $22{ }^{\circ} \mathrm{C}$. However, the flight activity of $S$. titanus mainly depends on the photoperiod, even though relative humidity is negatively correlated with flight (Lessio and Alma 2004b). The movement of $S$. titanus within the vineyard also depends on the vine density as well as on the canopy architecture (Lessio and Alma 2004a). This dual dependency of $S$. titanus is probably due to its movements being largely confined to the canopy (Lessio and Alma 2004a), where it moves along the vine row rather than transversely (Lessio et al. 2009a). Despite its low dispersal capabilities, in North America, there are seasonal population movements between vineyards and the surrounding forest vegetation (Weintraub and Beanland 2006).

Like in other vector-borne diseases, the estimated risk of plant infection differs greatly depending on the vector population size between years and also as a function of local environmental conditions (Gruber and Daugherty 2013). Models to improve the understanding of the spatiotemporal population and pattern of infective vector dynamics were developed. Most of them are phenology models that predict the dynamics of age structure, the beginning and the pattern of egg hatching, the occurrence of nymphal instars, and the emergence of adults (Rigamonti et al. 2011; Maggi et al. 2013; Rigamonti et al. 2013b). Others focused on biological parameters like the sex ratio (Lessio et al. 2009b), the seasonal progression of the proportion of infective vectors (Bressan et al. 2006; Lessio et al. 2009b), and the relationship between $S$. titanus population levels and diseased grapevines in the following year (Morone et al. 2007). Modeling is useful to better understand the biology of the insect and Flavescence dorée epidemiology and to better adjust $S$. titanus control. Recent modeling studies based on some of S. titanus' biological parameters may lead to further research that fills 
knowledge gaps in the vector's population dynamics, both in time and space, and particularly on the ability of the vector to colonize $S$. titanus-free vineyards.

Variation in vector populations and vector capacities leads to differential risks of plant infection. Climatic and trophic factors driving such population variations in different geographical settings could be modeled to improve S. titanus control.

\section{Relationships with phytoplasma: the vector competence}

\subsection{Feeding behavior and vectorial capacity}

Food is taken in by probing the conducting vessels of the leaves, preferentially the phloem, and also on the xylem and parenchyma (Carle and Moutous 1965). Surprisingly, although the presence of typical structures, like the joint presence of a well differentiated filter chamber and aquaporins (LeCaherec et al. 1997), suggests xylemophagous habits, the phloemophagy of $S$. titanus is confirmed by the vection of phytoplasma. An early study by Carle and Moutous (1965) of the salivary sheath's path inside the vine leaves confirms that $S$. titanus may draw in the xylem sap. Perforation of the epidermis is made between two cells. The path of the stylets within plant tissues is linear, oriented toward vascular tissue, and is intra- or intercellular, according to the arrangement of the cells encountered. The formation of the setal sheath begins at the cortical parenchyma. Less than $20 \%$ of the stylet bifurcations attain the wood parenchyma, the rest being divided equally between the xylem and phloem. No probing difference between males and females has ever been demonstrated. The nymphs prefer to feed on the small veins of the leaf blade, and the adults feed more readily on the larger veins or petioles. This preference is probably due to the difference between young instars and adult stylet lengths, but this could also be related to sap pressure. The study of these feeding behavior traits, only poorly known so far, should greatly benefit from the development of the electropenetrography technique that allows the fundamental processes of piercing-sucking insect feeding behavior to be studied (Chuche et al. 2011b).

From the first larval stage of $S$. titanus, phytoplasmas are passively acquired during feeding on infected plants (Schvester et al. 1969; Boudon-Padieu et al. 1989). A minimum feeding period is necessary to become infective, and the longer it lasts, the more likely the insect is to acquire the phytoplasma (Purcell 1982). Once infected, the insect remains a vector for the rest of its life (Christensen et al. 2005). The phytoplasma is drawn from the phloem by the stylets, then passes through the intestinal barrier, joins the hemolymph, and colonizes most of the vector organs. An incubation period of about 1 month, during which time the phytoplasma multiplies and colonizes the vector's body, is required before the vector becomes infectious (Boudon-Padieu 2000). In the insect, phytoplasmas first multiply in the cytoplasm of gastrointestinal tract cells, particularly those of the filter chamber, foregut, and midgut (Lefol et al. 1994). Phytoplasmas then reach the hemolymph by passing between the intestinal cells and colonizing all organs, including the fat body and brain, but not the sex glands. The salivary glands are a site of intense proliferation (Lefol et al. 1993, 1994). The phytoplasmal load increases in the hemolymph, and then in the salivary glands, suggesting either that the hemolymph is a late breeding site, or that it is colonized by the production of infected organs (Lefol et al. 1994). Once the concentration of phytoplasma in the salivary glands reaches a sufficient level, the infectious agent can be transmitted at an infectious dose to a healthy plant with every intake, until the death of the leafhopper. Unfortunately, several epidemiological traits, including the amount of phytoplasma ingested, the multiplication rate in S. titanus, and the amount of phytoplasma transmitted, are poorly known. However, the multiplication rate in the plant is known to be negatively related to temperature (Galetto et al. 2011). In the experimental Flavescence dorée leafhopper vector Euscelidius variegatus, D'Amelio et al. (2007) measured a Flavescence dorée phytoplasma titer increase from $1.4 \times 10^{3}$ phytoplasma genome units per nanogram of insect vector DNA 14 days after a 7 -day acquisition period to $2.5 \times 10^{6}$ 33 days after acquisition period.

The vertical transmission of Flavescence dorée is thought to be impossible because Flavescence dorée phytoplasma have never been observed in sexual organs (Schvester et al. 1969; Bressan et al. 2005a). However, since the 16SrI phytoplasma has been observed to transmit in this manner in S. titanus, sexual transmissibility seems to depend on the particular type of phytoplasma (Alma et al. 1997).

\subsection{Interactions between S. titanus and the phytoplasma} causing Flavescence dorée: the longevity of vector life after IP

Several vector-borne pathogens drive their vectors, with various effects on their biology and behavior (Maramorosch and Jensen 1963; Purcell 1982; Mayer et al. 2008; Sisterson 2009). Those effects can either be deleterious (Garcia Salazar et al. 1991; D'Amelio et al. 2008; Malagnini et al. 2010) or, conversely, beneficial, particularly in terms of longevity and fertility (Purcell 1988; Beanland et al. 2000; Ebbert and Nault 2001; Sugio et al. 2011). Flavescence dorée phytoplasma reduces the lifespan of infected males and females and also reduces female fecundity and fertility, leading ultimately to smaller offspring (Bressan et al. 2005a). Pathogenicity decreases with the age of vector-pathogen relationships, which suggests a recent association of $S$. titanus with Flavescence dorée phytoplasma (Madden and Nault 1983; Ebbert and Nault 2001; Elliot et al. 2003; Weintraub and Beanland 2006). However, the rather homogenous distribution over large areas in Europe will 
counterbalance a reduction in the virulence of the pathogen towards the vector (Elliot et al. 2003).

The transmission of phytoplasma strains responsible for Flavescence dorée is species specific in Europe, and $S$. titanus cannot transmit other phytoplasmas responsible for grapevine yellows in Europe (Carraro et al. 1994). However, S. titanus can transmit phytoplasma from the 16SrI group. Thus, several strains were found in natural populations, and these could be transmitted in the laboratory to broad bean (Vicia faba) (Alma et al. 1997). Laboratory transmission assays were successful with other phytoplasmas of the same group. Thus, a phytoplasma identified as belonging to the 16SrI-C called $\varphi$ (Boudon-Padieu et al. 1990) was experimentally transmitted to the vine by $S$. titanus (Caudwell et al. 1971). In addition, a 16SrI-B group phytoplasma was experimentally transmitted to Glebionis carinata (syn. Chrysanthemum carinatum), but with a low efficiency (Alma et al. 2001). S. titanus is also able to transmit Flavescence dorée to $V$. faba and probably also to C. carinatum (Caudwell et al. 1970). In North America, phytoplasmas related to Flavescence dorée were detected in S. titanus via enzyme-linked immunosorbent assay (Maixner et al. 1993) and PCR (Olivier et al. 2008), but they could not be identified more accurately.

In addition, $S$. titanus was expected to transmit the virus causing grapevine corky-bark disease (Moutous and Hevin 1986), whose major vector is the mealybug (Namba et al. 1991), but the Grapevine Virus B causing the disease was not known at the time. Thus, Koch's postulates could not be demonstrated, and transmission rates were only checked by symptom expression on susceptible grape cultivars. The putative role of $S$. titanus in corky-bark disease transmission needs to be confirmed by new studies.

Several parameters influence the transmission efficiency of Flavescence dorée. The transmission rate of the phytoplasma in the laboratory is higher in males than in females (Schvester et al. 1969). The same phenomenon was observed for the transmission by $S$. titanus of yellows close to Flavescence dorée in New York State (Maixner et al. 1993) and also in E. variegatus (Kuszala 1986; Boudon-Padieu et al. 1989). In addition, the proportion of males carrying phytoplasma is always higher in vineyards than that of females, and both rates increase during the season (Lessio et al. 2009b). Phytoplasma can be acquired from hatching, and the proportion of vectors carrying phytoplasma increases with the instar (Bressan et al. 2006). The more effective phytoplasma acquisition by older instars may be partly explained by the increased concentration of phytoplasma in phloem over time (Bressan et al. 2005b), and by different forms of feeding behaviors. Plant quality also has an influence on feeding behavior and, therefore, on the effectiveness of the acquisition of phytoplasma by $S$. titanus, with several known susceptible grape cultivars being better sources of inoculum (Bressan et al. 2005b). Different concentrations of phytoplasmas among tolerant and sensitive varieties (Bosco and Marzachi 2011; Eveillard et al. 2012), and a possible difference in feeding behavior on the two kinds of grapes, may explain the different rates of acquisition (Bressan et al. 2005b). The effectiveness of phytoplasma acquisition also depends on the infected plant species. Alma et al. (2001) have shown that the same phytoplasma could be acquired by three leafhopper species, Macrosteles quadripunctulatus, Euscelidius variegates, and Euscelidius incisus, depending on the host plant species. Thus, the acquisition of Flavescence dorée phytoplasma by S. titanus on broad bean is more efficient than on vine (Bressan et al. 2005b).

Feeding behavior is a key factor in the phytoplasma-vector relationship and, therefore, in the Flavescence dorée epidemic. The deleterious effects of Flavescence dorée phytoplasma on $S$. titanus suggest a recent association between the pathogen and the vector.

\section{Vector management: current options}

There is, as yet, no efficient way to control phytoplasma in the plant or vector. As in many insect-borne diseases, controlling the vector is the only current strategy. In addition to the use of insecticides, some prophylactic actions could be performed to decrease the risk of Flavescence dorée.

\subsection{Vector control}

Flavescence dorée phytoplasma is a quarantined pest in the EPPO region and was declared a quarantined pest by the European Union in 1993 (Directive 77/1993 amended 92/ 103). The declaration of the disease and the various control measures were made mandatory by two ministerial decrees in France (April 17, 1987 and April 1, 1994) and one in Italy (May 31, 2000). Control of the Flavescence dorée epidemic requires mandatory use of insecticides against the vector. Vector control is primarily directed against mobile instars (nymphs and adults) and is based on the use of insecticides. Treatments against eggs can also be applied in the winter. Currently, the mandatory control of $S$. titanus is based on one or two treatments a year in Italy (Belli et al. 2010), two in Switzerland (Jermini et al. 2007), and three, or possibly two, depending of the size of the vector population, in France (Trespaille-Barrau and Grosman 2011). Thus, in 2011, more than 450,000 ha were under mandatory control, representing almost $50 \%$ of French vineyards (Trespaillé-Barrau, 2012, personal communication). Presently, pyrethrinoids are used, with basic products costing between 4 and $25 € \mathrm{ha}^{-1}$ in France (Grossman, 2012, personal communication), while other neurotoxins and growth regulators are used in Italy and Switzerland (Table 4).

In France, reducing the three mandatory insecticide applications was tested from 2000 to 2003 , and since 2004 has been 
Table 4 Insecticides used against S. titanus

\begin{tabular}{|c|c|c|c|c|}
\hline Chemical class & Chemical name & Mode of action & Country & References \\
\hline Natural product & Pyrethrins & Neurotoxic & France, Italy, Switzerland & $\begin{array}{l}\text { COSVIR XI 2013; E-phy 2013; } \\
\text { OFAG } 2013\end{array}$ \\
\hline Neonicotinoid & Thiamethoxam & Neurotoxic & Italy & COSVIR XI 2013 \\
\hline Organophosphorus & Chlorpyriphos & Neurotoxic & France, Italy, Switzerland & $\begin{array}{l}\text { COSVIR XI 2013; E-phy 2013; } \\
\text { OFAG } 2013\end{array}$ \\
\hline \multirow[t]{8}{*}{ Pyrethrinoid } & Betacyfluthrin & Neurotoxic & France & E-phy 2013 \\
\hline & Cyfluthrin & Neurotoxic & France & E-phy 2013 \\
\hline & Cypermethrin & Neurotoxic & France, Italy & COSVIR XI 2013; E-phy 2013 \\
\hline & Deltamethrin & Neurotoxic & France, Italy & COSVIR XI 2013; E-phy 2013 \\
\hline & Esfenvalerate & Neurotoxic & France & E-phy 2013 \\
\hline & Cyhalothrin & Neurotoxic & France, Switzerland & E-phy 2013; OFAG 2013 \\
\hline & Tau-fluvalinate & Neurotoxic & France & E-phy 2013 \\
\hline & Acrinathrin & Neurotoxic & France, Italy & COSVIR XI 2013; E-phy 2013 \\
\hline Thiadiazin & Buprofezin & Growth regulator & Italy, Switzerland & COSVIR XI 2013; OFAG 2013 \\
\hline \multicolumn{5}{|l|}{ Blend } \\
\hline $\begin{array}{l}\text { Neonicotinoid }+ \text { Anthranilic } \\
\text { diamide }\end{array}$ & Thiamethoxam + Chlorantraniliprole & Neurotoxic & France & E-phy 2013 \\
\hline Organophosphorus & Dimethoate + Chlorpyriphos & Neurotoxic & France & E-phy 2013 \\
\hline \multirow[t]{2}{*}{ Organophosphorus + Pyrethroid } & Chlorpyriphos + Cypermethrin & Neurotoxic & France & E-phy 2013 \\
\hline & Chlorpyriphos + Deltamethrin & Neurotoxic & France, Italy & COSVIR XI 2013; E-phy 2013 \\
\hline
\end{tabular}

increasingly applied (Decoin et al. 2005; Trespaille-Barrau and Grosman 2011; van Helden et al. 2011). Rules determining the number of treatments depend on regional settings. In the Saint Emilion vineyard (East of Bordeaux) plots situated 2-4 km from a Flavescence dorée focus received no larvicide treatments, while one or two treatments against nymphs are applied in those that are closer (Dufour et al. 2008). Treatment against adults is made if more than three adults are caught on yellow sticky traps during a week. In Bordeaux, $90 \%$ of the vineyards received only two applications (Trespaille-Barrau and Grosman 2011). However, this insecticide reduction is costly (26€ $\mathrm{ha}^{-1}$ ) because of increased monitoring (Dufour et al. 2008), and the consequences of this reduction on the epidemic will be better known in the coming years. In the Piemonte region, the two treatments can be reduced to one if the $S$. titanus population level is under 0.02 nymphs per five leaves per plant and less than two adults are captured on three traps per season (Bosco and Mori 2013).

Treatment reductions cannot be used in vine nurseries. Indeed, all nurseries have to be treated from the first hatching of $S$. titanus to the adult instar (May to September) in France. The number of treatments performed depends on the persistence of the insecticide employed.

The mandatory control of $S$. titanus is problematic for organic production because organic growers can only use natural pyrethrins that are neither sufficiently efficient nor persistent, especially against adults, the most dispersive instar (Gusberti et al. 2008; Sivčev et al. 2010). It is also a problem for growers that decrease their insecticide use by practising pheromonal mating disruption to control the pests Lobesia botrana and Eupoecillia ambiguella (Lepidoptera, Tortricidae). Mandatory treatments impede their sustainable approach to agriculture. However, mating disruption using synthetic moth sexual pheromones against grape moth are rather limited in European viticulture, about 25,000 and 20,000 ha in France and Italy, respectively, in 2012. Prophylactic measures can be used to reduce vector populations. The destruction of woody canes carrying eggs after pruning reduces $S$. titanus numbers and, thus, Flavescence dorée transmission. Pruning was cited as a partial explanation for the differences in density observed in the early 1960s between two southwestern areas, Armagnac and the Chalosse (long pruning, highest densities), and Bordeaux (short pruning, lowest densities) (Schvester 1962; Schvester et al. 1962b).

\subsection{Use of healthy planting material}

The prophylaxis of plant material has unfortunately been neglected for years, while the relation of the epidemic to vine trading activities now receives more attention. It is possible to ensure vineyard safety by destroying the phytoplasmas that may be harbored by grapevine seedlings, and the eggs of $S$. titanus laid under the bark, by immersion in hot water (Caudwell et al. 1990, 1997; Linder et al. 2010). A 45-min immersion in water at $50{ }^{\circ} \mathrm{C}$ eliminates microorganisms and eggs without causing the death of vines (Caudwell et al. 1997). Hot-water treatments are compulsory in Australia and New Zealand for multiplicative materials, in Canada for 
imports from countries where phytoplasma diseases of grapevines occurs, are routinely used in France, and are being developed in certain other countries, like Italy and Switzerland (Bianco et al. 2000; Dupraz and Schaub 2007; Mannini 2007; Canadian Food Inspection Agency 2009).

6.3 The removal or control of Flavescence dorée and $S$. titanus reservoirs

The removal of diseased stocks and abandoned vines, as well as the new growth of wild vines, avoids the formation of disease reservoirs that might result in the contamination of nearby vineyards (Boudon-Padieu 2000). In addition, these areas can serve as refuges for the vector, therefore reducing the effectiveness of their control (Forte et al. 2009). In France, uprooting is mandatory for infected Flavescence dorée hosts, and when $20 \%$ of diseased plants are detected, the whole plot must be removed (Boudon-Padieu 2002). In Italy, however, stocks with grapevine yellows symptoms are uprooted only in areas with Flavescence dorée outbreaks (Belli et al. 2010). In Lombardy, the control strategy is partially based on the destruction of uncultivated vineyards (Belli et al. 2010), and recommendations to growers in the Piemonte region involve the destruction of wild vegetation surrounding the vineyard by mechanical and chemical means (Bosco and Mori 2013). After pruning, the burning or burying of egg-carrying cut wood is preferred to grinding because it suppresses more eggs (Cazenove and Planas 1991; Boudon-Padieu 2000; Bosco and Mori 2013). Since the nymphal density is higher on suckers than in the canopy, the frequent removing of suckers can contribute to decreased $S$. titanus population levels in vineyards (Schvester et al. 1962b; Bernard and Du Fretay 1988; Cazenove and Planas 1991; Posenato et al. 2001; Cara et al. 2013).

6.4 Reducing the probability of vector survival by biological control agents

S. titanus population levels observed on $V$. vinifera in France are significantly higher than those in the USA (Maixner et al. 1993), which suggests that the native natural enemies, which are more efficient in the original area, were not introduced with the vector. However, natural enemy pressure against S. titanus is lower in both continents (Schvester et al. 1962b; Bernard and Du Fretay 1988; Malausa and Sentenac 2011) than for other grape pests. In Europe, for example, grapevine moth larvae can be parasitized up to between 50 and $80 \%$ depending on the vineyard (Marchesini and Monta 1994; Thiéry et al. 2001; Bagnoli and Lucchi 2006; Xuéreb and Thiery 2006). In North America, several species of parasitoids, Hymenoptera Dryinidae and Diptera Pipunculidae were observed on S. titanus (1.3 and $0.8 \%$, respectively) (Barnett 1976), and also Hymenoptera Mymaridae and
Trichogrammatidae, but not with quantified parasitism rates (Table 5) (Malausa et al. 2003). Interestingly, S. titanus seems to have a special relationship with the predatory bug Malacocoris chlorizans (Hemiptera: Miridae). This bug does not feed on S. titanus but can stimulate its honeydew production through contact between its antennae and the abdomen of the leafhopper when feeding on the liquid (Carle 1965), as is the case in aphid-ant interactions (Stadler and Dixon 2005). These are laboratory observations, but vineyard monitoring showed that populations of $M$. chlorizans are associated and synchronized with the occurrence of S. titanus (Carle 1965).

Biological control of S. titanus has been attempted, either by releasing natural enemies from their native habitat or by increasing local natural enemy populations; however, these two strategies have yielded poor results so far (Malausa and Sentenac 2011). In France, the release of Gonatopus flavipes (Hymenoptera: Dryinidae) was performed during three successive years in two experimental sites (Burgundy and Côtes du Rhône vineyards). In total, 368 adults were released and 46,000 S. titanus were collected and examined. The best parasitism rate was very low, $<0.4 \%$ (Malausa and Sentenac 2011). The apparently very low efficiency of this parasitoid is magnified by the difficulty of rearing it.

\subsection{Vector monitoring}

The monitoring of $S$. titanus can be achieved using four main techniques, counting the number (1) of nymphs on the underside of leaves, (2) after beating, (3) using a suction apparatus as, for example, D-vac, and (4) using sticky traps, with the last two techniques being preferential for adults, which are more mobile than larvae (Table 6). The accuracy of these techniques is variable; thus, they should be considered only as estimates. For example, after rainfalls, nymphs were not observed on leaf counts for a period of up to 3 days (Bernard et al. 1988), while they were still present on the plot. All monitoring methods are susceptible to variations in efficiency depending on the weather, the season, the vineyard management, and plant position in the vineyard (internal or bordering). The effectiveness of traps is the most dependent on weather conditions (temperature, wind, and rain) and population density, which poses the problem of trap reliability in agronomy and plant protection. With low population densities, it is necessary to enhance the catch number in the plot to obtain a reliable estimate of population size (Jermini et al. 1992). Capture samples do not account for the relative importance of males and females, as more males than females are captured (Bosco et al. 1997; Lessio et al. 2009b). In addition, the sex ratio of trapping varies with location and the particular season, with more males being caught at the beginning of adult emergence, and more females at the end of the season (Lessio et al. 2009b). This time variation occurs because the males emerge first and have shorter lives than females (Bressan et al. 2005a). 
Table 5 Natural enemies of $S$. titanus

\begin{tabular}{|c|c|c|c|c|c|c|c|}
\hline & Order & Familly & Species & Kind of enemy & Target instar & Country & References \\
\hline \multirow[t]{15}{*}{ Insects } & \multirow[t]{2}{*}{ Diptera } & Pipunculidae & Eudorylas sp. & Parasitoid & Larvae; adults & France & Malausa and Sentenac 2011 \\
\hline & & Syrphidae & - & Predator & Larvae & France & Schvester et al. $1962 \mathrm{~b}$ \\
\hline & Hemiptera & Reduviidae & - & Predator & Larvae & France & Schvester et al. $1962 b$ \\
\hline & \multirow[t]{12}{*}{ Hymenoptera } & \multirow[t]{9}{*}{ Dryinidae } & Anteon masoni & Parasitoid & Larvae; adults & USA & Malausa et al. 2003 \\
\hline & & & Anteon pubicorne & Parasitoid & Larvae; adults & France & Malausa and Sentenac 2011 \\
\hline & & & Esagonatopus niger & Parasitoid & Larvae; adults & USA & Malausa et al. 2003 \\
\hline & & & Esagonatopus perdebilis & Parasitoid & Larvae; adults & USA & Malausa et al. 2003 \\
\hline & & & Gonatopus audax & Parasitoid & Larvae; adults & France & Malausa and Sentenac 2011 \\
\hline & & & Gonatopus clavipes & Parasitoid & Larvae; adults & France & Malausa and Sentenac 2011 \\
\hline & & & Gonatopus lunatus & Parasitoid & Larvae; adults & France & Malausa and Sentenac 2011 \\
\hline & & & Gonatopus peculiaris & Parasitoid & Larvae; adults & USA & Malausa et al. 2003 \\
\hline & & & Lonchodryinus flavus & Parasitoid & Larvae; adults & USA & Malausa et al. 2003 \\
\hline & & \multirow[t]{2}{*}{ Mymaridae } & Polynema sp. & Parasitoid & Eggs & USA & Malausa et al. 2003 \\
\hline & & & - & Parasitoid & Eggs & Europe & Malausa and Sentenac 2011 \\
\hline & & Trichogrammatidae & Oligosita sp. & Parasitoid & Eggs & USA & Malausa et al. 2003 \\
\hline \multirow[t]{2}{*}{ Mites } & \multirow[t]{2}{*}{ Acarina } & Anystidae & Anystis baccarum & Predator & Larvae & France & Bernard and Du Fretay 1988 \\
\hline & & Bdellidae & - & Predator & Larvae & France & Chuche, personal observation \\
\hline \multirow[t]{2}{*}{ Spiders } & \multirow[t]{2}{*}{ Araneae } & Philodromidae & - & Predator & Larvae & Italy & Chuche et al. 2011c \\
\hline & & Thomisidae & - & Predator & Larvae & Italy & Chuche et al. 2011c \\
\hline
\end{tabular}

Additionally, males are active before mating (Mazzoni et al. 2009c), while mated females must displace themselves to lay their eggs later in the season. The effect of color on trap efficiency is still controversial and not fully understood. A yellow color is mainly used and seems the most attractive to nymphs and adults in the field (Chuche et al. 2011a; Mazzoni et al. 2011), while a red color attracted females in a laboratory experiment (Mazzoni et al. 2011) and males in a vineyard study (Lessio and Alma 2004a). Globally, the use of yellow sticky traps seems to be an effective compromise for all stages and both sexes. The position of the traps in vineyards also has an effect. Indeed, horizontal positioning, either in the foliage or underneath the plants, allows more insects to be captured than vertical positioning (Jermini et al. 1992).

In an integrated pest management context, the use of control methods is dependent on monitoring. The presence and the population level of the vector are key factors in the decision to trigger a control and the type of control, but also to assess its effectiveness. To overcome the imprecision of monitoring methods, monitoring plans were developed (Jermini et al. 1993; Lessio and Alma 2006; Rigamonti et al. 2013a).

Currently, the Flavescence dorée risk is limited by vector control, the use of healthy plant materials and the removal of potential phytoplasma reservoirs. To decrease pesticide use, a cross survey of the vector population and of the infected hosts triggers the mandatory treatments.

\section{Future directions for research and management}

\subsection{Vector control}

Knowledge of the phenology of S. titanus is crucial for a timely application of insecticides. A phenology model was

Table 6 Monitoring methods of $S$. titanus

\begin{tabular}{|c|c|c|c|c|}
\hline Method & Which instar? & Efficiency & Factors of variation & Use \\
\hline Countings & Nymphs & Good & Rainfalls & $\begin{array}{l}\text { Time consuming, needs skilled people able to } \\
\text { recognize quickly } S \text {. titanus }\end{array}$ \\
\hline Beating the canopy & Mainly nymphs & Good & Rainfalls & Catch many arthropods and needs sorting \\
\hline Suction collect & All & Good & Rainfalls & $\begin{array}{l}\text { Catch a lot of arthropods and plant material, } \\
\text { Needs many sorting }\end{array}$ \\
\hline Yellow sticky traps & Mainly adults & Poor & $\begin{array}{l}\text { Male and females differentially attracted. } \\
\text { Depends upon adults' displacement. } \\
\text { Wind and rainfalls }\end{array}$ & Easy even if non selective \\
\hline
\end{tabular}


Table 7 Summary of important key research topics for the management of $S$. titanus

\begin{tabular}{|c|c|c|}
\hline Research topics & Possible application & Status \\
\hline \multirow[t]{2}{*}{ Vector feeding behavior } & Feeding deterrents/push-pull & To be evaluated \\
\hline & Cultivar selection & To be evaluated \\
\hline \multirow[t]{2}{*}{ Symbionts characteristics } & Reducing feeding behavior and fitness & In progress \\
\hline & Blocking pathogen transmission & In progress \\
\hline \multirow[t]{3}{*}{ Field dispersion characteristics } & Developing spatial models & To be urgently developed \\
\hline & Improving risk assessment and insecticide treatment decision & In progress \\
\hline & Adapting the vineyard architecture/pruning type & To be evaluated \\
\hline \multirow[t]{2}{*}{ Relationships between the vector and the pathogen } & Understanding how the phytoplasma can alter the behavior of the vector & To be urgently developed \\
\hline & Evaluating the ability to transmit other pathogens & To be evaluated \\
\hline \multirow[t]{2}{*}{ Better knowledge of the FD host plant system } & Characterizing the risky plant reservoirs & To be evaluated \\
\hline & Managing of the weed plants surrounding vineyard & In progress \\
\hline \multicolumn{3}{|l|}{ Phenology of the vector/population dynamic } \\
\hline 1-Population dynamic & Adjusting the treatment periods of the year & In progress \\
\hline 2-Voltinism & Developing temporal dynamic models & To be urgently developed \\
\hline Mating disruption & Transferring semi-fields results to a larger scale & In progress \\
\hline
\end{tabular}

designed by Rigamonti et al. (2011) to improve the timing of insect growth regulator applications. A population model was also developed and allowed to determine that S. titanus dynamics are generally more susceptible to variations in biological timing parameters than rates (Maggi et al. 2013). These models support decision makers in making pest management operations more sustainable while strongly reducing the risk of Flavescence dorée's spread. Similar studies are needed to improve vector population control. These should include the effect of temperature on the dynamics of hatching that, in turn, affects the dynamics of the successive instars (Chuche and Thiéry 2009). Since improved timing requires reliable indicators of the insect's presence, the development of more efficient monitoring strategies is crucial (Table 7). Additionally, the dispersal capacity and the effect of vineyard architecture on the vector's dispersion require more attention.

\subsection{Breaking the phytoplasma cycle}

To date, no resistance or tolerance to grapevine yellows has been detected in the Vitis species considered (Laimer et al. 2009), despite the use of phytoplasma resistance detection methods (Jarausch et al. 1999; Sinclair et al. 2000; Cardeña et al. 2003). Since selection and breeding methods do not seem to be promising solutions over the short and medium term, the development of transgenic grapevines represents a perspective (Laimer et al. 2009). Conclusive tests have been conducted with Paulownia sp. expressing antibacterial peptides of the Lepidoptera Hyalophora cecropia (Du et al. 2005). However, tests conducted with transgenic tobacco plants targeting the stolbur phytoplasma have so far been unsuccessful (Malembic-Maher et al. 2005). While using genetically modified vines may constitute a technical issue, the consumer acceptance of genetically modified organisms for high quality and expensive wines may represents a limiting factor.

Symbiosis is a key driver of much insect biology, especially in Hemiptera. Symbionts may confer several benefits, such as improving nutrition, countering the host's defenses, increasing protection against natural enemies, and improving development and reproduction (Wu et al. 2006; Oliver et al. 2010; Frago et al. 2012); however, they may also have adverse effects in some cases, such as lifespan shortening and fertility reduction (Alam et al. 2011; Nakamura et al. 2012; Schraiber et al. 2012). Since symbionts are essential to insect development and adaptation, innovative and exciting biological vector control methods attempt to use such symbiotic relationships in controlling populations of vector-borne diseases (Hurd 2003; Riehle and Jacobs-Lorena 2005). Among natural biological control agents, the use of endosymbionts, like Wolbachia, seems encouraging, especially those acting to shorten lifespans (Cook et al. 2008) or block pathogen transmission (Bian et al. 2013). Interestingly, symbiotic bacteria of the genus Cardinium, which are responsible for impaired reproduction and behavior, were found in natural populations of both $S$. titanus sexes with a high prevalence ( $>94 \%$ ) and in different organs (ovaries, fat body, midgut, and salivary glands) (Marzorati et al. 2006; Sacchi et al. 2008). Symbionts were also observed coexisting with " $\mathrm{Ca}$. Phytoplasma vitis" in the same $S$. titanus organs, which raises questions about the possible role of this bacterium in the transmission of the phytoplasma (Marzorati et al. 2006). Socalled "yeast-like" symbiotes belonging to the ascomycete lineage, which could play a metabolic role and could be transmitted vertically, have also been discovered (Sacchi et al. 2008). Finally, S. titanus can also host symbiotic bacteria of 
the genus Asaia, transmitted vertically by the female as well as by the male during mating, that can equally be acquired horizontally during feeding (Marzorati et al. 2006; Crotti et al. 2009). Some authors already suggested using these symbionts to decrease the vector's capacity for $S$. titanus (Marzorati et al. 2006; Crotti et al. 2009). In coming years, this approach should receive further consideration (Table 7).

\subsection{Integrated vector management}

Integrated vector management is currently the most promising and feasible management technique for sustainable viticulture. Behavior modification is an interesting $S$. titanus population management model (Table 7). The two mains methods are mating disruptions and push-pull strategies.

As discussed, S. titanus uses vibrations transmitted by the leaf to mate and, therefore, vibrational disturbances would cause mating disruptions. Sexual disruption was successful in the laboratory and the first field-scale experiments were also promising (Mazzoni et al. 2009b; Eriksson et al. 2012). The challenge is to transfer these results to a larger scale. A similar strategy could not be extended to larval behavior disturbances because the nymphs do not use communication based on vibrations (Chuche et al. 2011c).

"Push-pull" strategies involve manipulating insect behavior via the combined use of attractive and repulsive items, including lures or plants capable of drawing pests into an area where they will be destroyed (Cook et al. 2007). The use of this technique against vectors of phytoplasma in grapes has already shown promising results against $H$. obsoletus in Israel (Zahavi et al. 2007), and could be effective against $S$. titanus. Repellents could include kaolinite clay particles, which have been employed in field trials and seem good candidates against piercing-sucking insects. They are already used in North American vineyards (Daniel et al. 2005; Duval and Weill 2007; Tubajika et al. 2007; Marko et al. 2008). As mentioned above, American Vitis are more attractive than $V$. vinifera. Thus, we could combine less attractive harvested grapes after treatment, with kaolin particles for example, with vineyard borders of more attractive American Vitis. Leafhoppers would be pushed from the crop while simultaneously being pulled to the American Vitis. Growers could then control S. titanus populations by spotted insecticide applications or the application of mineral oils to bark (Caudwell et al. 1972).

The development of alternative sustainable methods or strategies is now required to reduce insecticide use and to increase the control efficiency (Table 7). In the short term, new models could support making pest management operations more sustainable. In the long term, innovative techniques involving symbionts, mating disruptions, and/or push-pull strategies could improve $S$. titanus and Flavescence dorée control with less impact on the environment.
Acknowledgments We thank Dr Sylvie Malembic-Maher for comments on the manuscript, and Dr Mauro Jermini, Jacques Grosman, and Jean-Michel Trespaillé-Barrau for allowing us to quote personal unpublished observations. The surface treated by mating disruption in Italy was provided by $\operatorname{Pr}$ A. Lucchi. We are very grateful to all the European researchers who shared their knowledge with us and to Pascal Salar, UMR Biologie du Fruit et Pathologie, for providing the pictures of S. titanus nymphs and adults. We also appreciate the constructive efforts of anonymous reviewers to improve our original manuscript. This work is part of the Labex COTE project and has been supported by grants from the Conseil Interprofessionnel des Vins de Bordeaux, the Aquitaine region and INRA Santé des Plantes et Environnement department.

\section{References}

Alam U, Medlock J, Brelsfoard C, Pais R, Lohs C, Balmand S, Carnogursky J, Heddi A, Takac P, Galvani A, Aksoy S (2011) Wolbachia symbiont infections induce strong cytoplasmic incompatibility in the tsetse fly Glossina morsitans. PLoS Pathog 7: e1002415. doi:10.1371/journal.ppat.1002415

Alma A, Bosco D, Danielli A, Bertaccini A, Vibio M, Arzone A (1997) Identification of phytoplasmas in eggs, nymphs and adults of Scaphoideus titanus Ball reared on healthy plants. Insect Mol Biol 6:115-121. doi:10.1111/j.1365-2583.1997.tb00079.x

Alma A, Palermo S, Boccardo G, Conti M (2001) Transmission of Chrysanthemum yellows, a subgroup 16SrI-B phytoplasma, to grapevine by four leafhopper species. J Plant Pathol 83:181-187. doi:10.4454/jpp.v83i3.1127

Angelini E, Negrisolo E, Clair D, Borgo M, Boudon-Padieu E (2003) Phylogenetic relationships among Flavescence dorée strains and related phytoplasmas determined by heteroduplex mobility assay and sequence of ribosomal and nonribosomal DNA. Plant Pathol 52: 663-672. doi:10.1046/j.1365-3059.2003.00917.x

Arnaud G, Malembic-Maher S, Salar P, Bonnet P, Maixner M, Marcone C, Boudon-Padieu E, Foissac X (2007) Multilocus sequence typing confirms the close genetic interrelatedness of three distinct flavescence doree phytoplasma strain clusters and group $16 \mathrm{SrV}$ phytoplasmas infecting grapevine and alder in Europe. Appl Environ Microbiol 73:4001-4010. doi:10.1128/aem.02323-06

Audusseau H, Nylin S, Janz N (2013) Implications of a temperature increase for host plant range: predictions for a butterfly. Ecolo Evol 3:3021-3029. doi:10.1002/ece3.696

Avramov Z, Ivanova I, Laginova M (2011) Screening for phytoplasma presence in leafhoppers and planthoppers collected in Bulgarian vineyards. Bull Insectol 64:S115-S116

Baggiolini M, Canevascini V, Caccia R, Tencalla Y, Sobrio G (1968) Présence dans le vignoble du Tessin d'une cicadelle néarctique nouvelle pour la Suisse, Scaphoideus littoralis Ball. (Hom., Jassidae), vecteur possible de la flavescence dorée. Bull Soc Entomol Suisse 40:270-275

Bagnoli B, Gargani E (2011) Survey on Scaphoideus titanus egg distribution on grapevine. IOBC/WPRS Bull 67:233-237

Bagnoli B, Lucchi A (2006) Parasitoids of Lobesia botrana (Den. \& Schiff.) in Tuscany. IOBC/WPRS Bull 29:139-142

Bagnoli B, Ferretti L, Trivellone V, Nuccitelli L, Pasquini G (2008) Occurrence of Scaphoideus titanus in Latium region. Petria 18:304-308

Barnett DE (1976) A revision of the Nearctic species of the genus Scaphoideus (Homoptera: Cicadellidae). Trans Am Entomol Soc 102:485-593

Beanland L, Hoy CW, Miller SA, Nault LR (2000) Influence of aster yellows phytoplasma on the fitness of aster leafhopper (Homoptera: Cicadellidae). Ann Entomol Soc Am 93:271-276. doi:10.1603/ 0013-8746(2000)093[0271:IOAYPO]2.0.CO;2 
Beanland L, Noble R, Wolf TK (2006) Spatial and temporal distribution of North American grapevine yellows disease and of potential vectors of the causal phytoplasmas in Virginia. Environ Entomol 35:332-344. doi:10.1603/0046-225X-35.2.332

Beirne BP (1956) Leafhoppers (Homoptera: Cicadellidae) of Canada and Alaska. Can Entomol 88:1-180. doi:10.4039/entm8802fv

Belli G, Fortusini A, Rui D (1985) Recent spread of flavescence dorée and its vector in vineyards of Northern Italy. Phytopathol Mediterr 24:189-191

Belli G, Bianco PA, Conti M (2010) Grapevine yellows in Italy: past, present and future. J Plant Pathol 92:303-326. doi:10.4454/jpp. v92i2.172

Bernard P, Du Fretay G (1988) Dynamique de population de Scaphoideus titanus, vecteur de la Flavescence dorée dans l'Aude en 1987. Bull Tech Inf 433(434):457-464

Bernard P, Du Fretay G, Gorguos M, Tassart V (1988) Hypothèse d'une deuxième génération de Scaphoideus titanus. Def Veg 251:17-21

Bertaccini A, Duduk B (2009) Phytoplasma and phytoplasma diseases: a review of recent research. Phytopathol Mediterr 48:355-378

Bertin S, Guglielmino CR, Karam N, Gomulski LM, Malacrida AR, Gasperi G (2007) Diffusion of the Nearctic leafhopper Scaphoideus titanus Ball in Europe: a consequence of human trading activity. Genetica 131:275-285. doi:10.1007/s10709-006-9137-y

Bian G, Joshi D, Dong Y, Lu P, Zhou G, Pan X, Xu Y, Dimopoulos G, Xi Z (2013) Wolbachia invades Anopheles stephensi populations and induces refractoriness to Plasmodium infection. Science 340:748751. doi:10.1126/science. 1236192

Bianco PA, Fortusini A, Scattini G, Casati P, Carraro S, Torresin GC (2000) Prove di risanamento di materiale viticolo affetto da Flavescenza dorata mediante termoterapia. Inf Fitopatol 50:43-49

Bonfils J, Schvester D (1960) Les cicadelles (Homoptera Auchenorhyncha) dans leurs rapports avec la vigne dans le SudOuest de la France. Ann Epiphyt 3:325-336

Bosco D, Marzachi C (2011) Flavescenza dorata in cv Barbera e Nebbiolo: incidenza, risanamento e suscettibilita al patogeno. Prot Col 2:21-23

Bosco D, Mori N (2013) "Flavescence dorée" vector control in Italy. Phytopathogenic Mollicutes 3:40-43. doi:10.5958/j.2249-4677.3.1.009

Bosco D, Alma A, Arzone A (1997) Studies on population dynamics and spatial distribution of leafhoppers in vineyards (Homoptera: Cicadellidae). Ann Appl Biol 130:1-11. doi:10.1111/j.1744-7348. 1997.tb05778.x

Bosio G, Rossi A (2001) Ciclo biologico in Piemonte di Scaphoideus titanus. Inf Agrar 57:75-78

Boubals D, Caudwell A (1971) Une épidémie de jaunisse dans le vignoble corse: probablement la flavescence dorée. Prog Agric Vitic 88:355-364

Boudon-Padieu E (2000) Cicadelle vectrice de la flavescence dorée, Scaphoideus titanus Ball, 1932. In: Stockel J (ed) Ravageurs de la vigne. Féret, Bordeaux, pp 110-120

Boudon-Padieu E (2002) Flavescence dorée of the grapevine: knowledge and new developments in epidemiology, etiology and diagnosis. In: Canova A (ed) ATTI Giornate Fitopatologiche, Baselga di Piné (Trento), Italy, 2002. pp 15-34

Boudon-Padieu E, Larrue J, Caudwell A (1989) ELISA and dot-blot detection of Flavescence dorée-MLO in individual leafhopper vectors during latency and inoculative state. Curr Microbiol 19:357364. doi:10.1007/BF01570882

Boudon-Padieu E, Larrue J, Caudwell A (1990) Serological detection and characterization of grapevine Flavescence dorée MLO and other plant MLOs. IOM Lett 1:217-218

Bressan A, Girolami V, Boudon-Padieu E (2005a) Reduced fitness of the leafhopper vector Scaphoideus titanus exposed to Flavescence dorée phytoplasma. Entomol Exp Appl 115:283-290. doi:10.1111/j.15707458.2005.00240.x
Bressan A, Spiazzi S, Girolami V, Boudon-Padieu E (2005b) Acquisition efficiency of Flavescence dorée phytoplasma by Scaphoideus titanus Ball from infected tolerant or susceptible grapevine cultivars or experimental host plants. Vitis 44:143-146

Bressan A, Larrue J, Boudon-Padieu E (2006) Patterns of phytoplasmainfected and infective Scaphoideus titanus leafhoppers in vineyards with high incidence of Flavescence dorée. Entomol Exp Appl 119: 61-69. doi:10.1111/j.1570-7458.2006.00391.x

Budinščak Ž, Križanac I, Mikec I, Seljak G, Škorić D (2005) Vektori fitoplazmi vinove loze u Hrvatskoj. Glas Biljn Zaštite 5:240-245

Canadian Food Inspection Agency (2009) Directive D-94-34 May 27, 2009 (2nd revision) import requirements for grapevine propagative material. http://www.inspection.gc.ca/plants/plant-protection/ directives/horticulture/d-94-34/eng/1321940472117/ 1321940673198\#c4. Accessed 09 October 2012.

Cara C, Trivellone V, Linder C, Junkert J, Jermini M (2013) Influence de la gestion des repousses du tronc et du bois de taille sur les densites de Scaphoideus titanus. Rev Suisse Vitic Arboric Hortic 45:114-119

Cardeña R, Ashburner GR, Oropeza C (2003) Identification of RAPDs associated with resistance to lethal yellowing of the coconut (Cocos nucifera L.) palm. Sci Hortic 98:257-263. doi:10.1016/S03044238(02)00162-0

Carle P (1965) Relations alimentaires entre Malacocoris chlorizans $\mathrm{Pz}$ (Hémipt. Hétérop. "Miridae") et Scaphoideus littoralis Ball. (Hémipt. Homopt. "Jassidae") sur les Vitis dans le Sud-Ouest de la France. Rev Zool Agr Appl 7-9:72-78

Carle P, Moutous G (1965) Observations sur le mode de nutrition sur vigne de quatre espèces de cicadelles. Ann Epiphyt 16:333-354

Carraro L, Loi N, Kuszala C, Clair D, Boudon-Padieu E, Refatti E (1994) On the ability-inability of Scaphoideus titanus to transmit different grapevine yellow agents. Vitis 33:231-234

Carton Y, Sorensen C, Smith J, Smith E (2007) Une coopération exemplaire entre entomologistes français et américains pendant la crise du Phylloxera en France (1868-1895). Ann Soc Entomol Fr 43:103-125

Caudwell A (1957) Deux années d'études sur la Flavescence dorée, nouvelle maladie grave de la vigne. Ann Amelior Plant 4:359-393

Caudwell A (1964) Identification d'une nouvelle maladie à virus de la vigne, la "Flavescence dorée". Etude des phénomènes de localisation des symptômes et de rétablissement. Ann Epiphyt 15(Hors Série 1), 193 pp

Caudwell A, Larrue J (1986) La flavescence dorée dans le Midi de la France et dans le Bas-Rhône. Prog Agric Vitic 103:517-523

Caudwell A, Kuszala C, Bachelier JC, Larrue J (1970) Transmission de la Flavescence dorée de la vigne aux plantes herbacées par l'allongement du temps d'utilisation de la cicadelle Scaphoideus littoralis BALL et l'étude de sa survie sur un grand nombre d'espèces végétales. Ann Pytopathol 2:415-428

Caudwell A, Larrue J, Kuszala C, Bachelier JC (1971) Pluralité des jaunisses de la vigne. Ann Pytopathol 3:95-105

Caudwell A, Brun P, Fleury A, Larrue J (1972) Les traitements ovicides contre la cicadelle vectrice, Scaphoideus littoralis (Ball), leur intérêt dans la lutte contre la flavescence dorée en Corse et dans les autres régions. Vignes Vins 21:5-10

Caudwell A, Moutous G, Larrue J, Fos A, Blancon G, Schick JP (1974) Les épidémies de Flavescence dorée en Armagnac et en Corse et les nouvelles perspectives de lutte contre le vecteur par des traitements ovicides d'hiver. Bull Tech Inf 294:783-794

Caudwell A, Larrue J, Valat C, Grenan S (1990) Les traitements à l'eau chaude des bois de vigne atteints de la Flavescence dorée. Prog Agric Vitic 107:281-286

Caudwell A, Larrue J, Boudon-Padieu E, McLean GD (1997) Flavescence dorée elimination from dormant wood of grapevines by hot-water treatment. Aust J Grape Wine Res 3:21-25. doi:10. 1111/j.1755-0238.1997.tb00112.x 
Cazenove R, Planas R (1991) Lutte contre la flavescence dorée de la vigne dans le cadre de l'agriculture biologique. Prog Agric Viticole 108:44-46

Chireceanu C, Ploaie PG, Gutue M, Nicolae I, Stan C, Comsa M (2011) Detection of the Auchenorrhyncha fauna associated with grapevine displaying yellows symptoms in Romania. Acta Phytopathol Entomol Hung 46:253-260. doi:10.1556/APhyt.46.2011.2.9

Christensen NM, Axelsen KB, Nicolaisen M, Schulz A (2005) Phytoplasmas and their interactions with hosts. Trends Plant Sci 10:526-535. doi:10.1016/j.tplants.2005.09.008

Chuche J (2010) Comportement de Scaphoideus titanus, conséquences spatiales et démographiques. Ph.D., Bordeaux University, Bordeaux. Available at http://www.theses.fr/2010BOR21771

Chuche J, Thiéry D (2009) Cold winter temperatures condition the egghatching dynamics of a grape disease vector. Naturwissenschaften 96:827-834. doi:10.1007/s00114-009-0541-x

Chuche J, Thiéry D (2012) Egg incubation temperature differently affects female and male hatching dynamics and larval fitness in a leafhopper. Ecol Evol 2:732-739. doi:10.1002/ece3.89

Chuche J, Boursault A, Thiery D (2011a) Preliminary study of the aggregative behaviour of Scaphoideus titanus larvae. IOBC/WPRS Bull 67:239-244

Chuche J, Sauvion N, Thiery D (2011b) Electropenetrography, a tool to investigate the feeding behaviour of sucking insects: development of this technique to Scaphoideus titanus. IOBC/WPRS Bull 67:299303

Chuche J, Thiery D, Mazzoni V (2011c) Do Scaphoideus titanus (Hemiptera: Cicadellidae) nymphs use vibrational communication? Naturwissenschaften 98:639-642. doi:10.1007/s00114011-0808-x

Clerc L, Linder C, Gunthart H (1997) Première observation en Suisse romande de la cicadelle Scaphoideus titanus Ball (Homoptera, Jassidae), vecteur de la flavescence dorée de la vigne. Rev Suisse Vitic Arboricult Hortic 29:245-247

Čokl A, Virant-Doberlet M (2003) Communication with substrate-borne signals in small plant-dwelling insects. Ann Rev Entomol 48:29-50. doi:10.1146/annurev.ento.48.091801.112605

Compton SG (2002) Sailing with the wind: dispersal by small flying insects. Dispersal ecology. Blackwell Science Ltd, Oxford

Cook SM, Khan ZR, Pickett JA (2007) The use of push-pull strategies in integrated pest management. Ann Rev Entomol 52:375-400. doi:10. 1146/annurev.ento.52.110405.091407

Cook PE, McMeniman CJ, O'Neill SL (2008) Modifying insect population age structure to control vector-borne disease. In: Aksoy S (ed) Transgenesis and the management of vector-borne disease, vol 627 , Advances in experimental medicine and biology. Springer, New York, pp 126-140. doi:10.1007/978-0-387-78225-6_11

Cosvir XI (2013) Fitofarmaci e Sostanze Attive. Centro Ricerca Per la Patologia Vegetale. Ministero delle politiche agricole alimentari e forestali Unità dirigenziale COSVIR XI - Servizio fitosanitario centrale. http://www.sian.it/fitovis/. Accessed 04 April 2013

Cravedi P, Mazzoni E, Cervato P (1993) Osservazioni sulla biologia di Scaphoideus titanus Ball (Homoptera: Cicadellidae). Redia 76:57-70

Credi R (1989) Flavescenza dorata della vite in Emilia-Romagna: evoluzione della mallattia nelle piante e suoi effetti sulla produczione e sullo sviluppo vegetativo. Phytopathol Mediterr 28:113-121

Crotti E, Damiani C, Pajoro M, Gonella E, Rizzi A, Ricci I, Negri I, Scuppa P, Rossi P, Ballarini P, Raddadi N, Marzorati M, Sacchi L, Clementi E, Genchi M, Mandrioli M, Bandi C, Favia G, Alma A, Daffonchio D (2009) Asaia, a versatile acetic acid bacterial symbiont, capable of cross-colonizing insects of phylogenetically distant genera and orders. Environ Microbiol 11:3252-3264. doi:10.1111/j. 1462-2920.2009.02048.x

Dalin P (2011) Diapause induction and termination in a commonly univoltine leaf beetle (Phratora vulgatissima). Insect Sci 18:443450. doi:10.1111/j.1744-7917.2011.01417.x
D’Amelio R, Marzachi C, Bosco D (2007) Double infection of 'Candidatus Phytoplasma asteris' and "flavescence dorée" phytoplasma in the vector Euscelidius variegatus. Bull Insectol 60:223-224

D'Amelio R, Palermo S, Marzachi C, Bosco D (2008) Influence of Chrysanthemum yellows phytoplasma on the fitness of two of its leafhopper vectors, Macrosteles quadripunctulatus and Euscelidius variegatus. Bull Insectol 61:349-354

Daniel C, Pfammatter W, Kehrli P, Wyss E (2005) Processed kaolin as an alternative insecticide against the European pear sucker, Cacopsylla pyri (L.). J Appl Entomol 129:363-367. doi:10.1111/j.1439-0418. 2005.00981.x

Danise B, Griffo R, Pesapane G, Scognamiglio G, Tropiano F (2005) Presenza massiccia di scafoideo in Campania (a large-scale presence of Scaphoideus in Campania). Inf Agrar 61:73-75

Daugherty MP, Lopes JRS, Almeida RPP (2010) Vector within-host feeding preference mediates transmission of a heterogeneously distributed pathogen. Ecol Entomol 35:350-366. doi:10.1111/j.13652311.2010.01189.x

de Sousa E, Casati P, Cardoso F, Baltazar C, Durante G, Quaglino F, Bianco PA (2010) Flavescence dorée phytoplasma affecting grapevine (Vitis vinifera) newly reported in Portugal. Plant Pathol 59:398398. doi:10.1111/j.1365-3059.2009.02130.x

Decante D, van Helden M (2006) Population ecology of Empoasca vitis (Gothe) and Scaphoideus titanus (Ball) in Bordeaux vineyards: influence of migration and landscape. Crop Prot 25:696-704. doi: 10.1016/j.cropo.2005.09.016

Decoin M, Herlemont B, Chiron MF, Trespaille-Barrau JM, Speich P, Girardet C, Constant N (2005) Flavescence dorée la quadrature de la cicadelle: quatre avis de recherche pour diminuer le nombre de traitements insecticides sur la vigne en preservant leur efficacité. Phytoma 586:29-31

Delic D, Seljak G, Martin M, Ermacora P, Carraro L, Myrta A, Duric G (2007) Surveys for grapevine yellows phytoplasmas in Bosnia and Herzegovina. Bull Insectol 60:369-370

Della Giustina W (1989) Homoptères Cicadellidae volume 3, compléments aux ouvrages d'Henri Ribaut. Faune de France 73. Fédération française des sociétés de sciences naturelles, Paris

Delong DM (1948) The leafhoppers, or Cicadellidae, of Illinois (Eurymelinae - Balcluthinae). Bull Ill Nat Hist Surv 24:91-376

Der Z, Koczor S, Zsolnai B, Ember I, Kolber M, Bertaccini A, Alma A (2007) Scaphoideus titanus identified in Hungary. Bull Insectol 60: 199-200

DRAAF-SRAL Champagne-Ardennes, CIVC (2012) Jaunisses à phytoplasmes de la vigne. Flavescence dorée ou bois noir, bilan des prospections 2012. Bulletin de Santé du Végétal Vigne. BSV spécifique du 21 décembre 2013

Drobnjakovic T, Peric P, Marcic D, Picciau L, Alma A, Mitrovic J, Duduk B, Bertaccini A (2011) Leafhoppers and cixiids in phytoplasmainfected carrot fields: species composition and potential phytoplasma vectors. Pestic Fitomedicina 25:311-318. doi:10.2298/pif1004311d

Du T, Wang Y, Hu QX, Chen J, Liu S, Huang WJ, Lin ML (2005) Transgenic Paulownia expressing shiva-1 gene has increased resistance to Paulownia witches' broom disease. J Integr Plant Biol 47: 1500-1506. doi:10.1111/j.1744-7909.2005.00168.x

Duduk B, Botti S, Ivanovic M, Krstic B, Dukic N, Bertaccini A (2004) Identification of phytoplasmas associated with grapevine yellows in Serbia. J Phytopathol 152:575-579. doi:10.1111/j.1439-0434.2004. 00898.x

Dufour MC, Garcia C, Verpy A, Van Helden M (2008) Aménagement, en Gironde, de la lutte contre la Flavescence dorée pour une diminution des intrants phytosanitaires. Rev Fr Oenol 228:228

Dupraz P, Schaub L (2007) Lutte contre le phytoplasme de la flavescence dorée: l'eau chaude a été réinventée! Rev Suisse Vitic Arboric Hortic 39:113-115

Duval J, Weill A (2007) Manuel des intrants bio: un recueil des intrants commerciaux autorisés en production végétale biologique et 
disponibles au Québec. Club agroenvironnemental Bio-Action, Napierville

Ebbert MA, Nault LR (2001) Survival in Dalbulus leafhopper vectors improves after exposure to maize stunting pathogens. Entomol Exp Appl 100:311-324. doi:10.1046/j.1570-7458.2001.00878.x

Elliot SL, Adler FR, Sabelis MW (2003) How virulent should a parasite be to its vector? Ecology 84:2568-2574. doi:10.1890/02-8013

E-phy (2013) Le catalogue des produits phytopharmaceutiques et de leurs usages des matières fertilisantes et des supports de culture homologués en France. Ministère de 1'Agriculture et de l'Agroalimentaire. http://e-phy.agriculture.gouv.fr/. Accessed 04 April 2013

EPPO/CABI (1997) Quarantine pests for Europe, 2nd edn. CAB International, Wallingford

Eriksson A, Anfora G, Lucchi A, Virant-Doberlet M, Mazzoni V (2011) Inter-plant vibrational communication in a leafhopper insect. PLoS ONE 6. doi:10.1371/journal.pone.0019692

Eriksson A, Anfora G, Lucchi A, Lanzo F, Virant-Doberlet M, Mazzoni V (2012) Exploitation of insect vibrational signals reveals a new pethod of pest management. PLoS ONE 7:5. doi:10.1371/journal. pone.0032954

Eveillard S, Labroussaa F, Salar P, Danet JL, Hevin C, Perrin M, Masson J, Foissac X, Malembic-Maher S (2012) Looking for resistance to the Flavescence doree disease among Vitis vinifera cultivars and other Vitis species. In: Proceedings of the 17th Congress of the International Council for the Study of Virus and Virus-like Diseases of the Grapevine (ICVG), Davis, California, USA, 7-14 October 2012. pp 234-235

Filippin L, Jovi J, Cvrkovi T, Forte V, Clair D, Tosevski I, Boudon-Padieu E, Borgo M, Angelini E (2009) Molecular characteristics of phytoplasmas associated with Flavescence dorée in clematis and grapevine and preliminary results on the role of Dictyophara europaea as a vector. Plant Pathol 58:826-837. doi:10.1111/j. 1365-3059.2009.02092.x

Forte V, Borgo M, Dalla Cia L, Angelini E (2009) High occurence of Scaphoideus titanus adults on wild rootstocks in Nort Eastern Italy. In: Extended abstracts 16th Meeting of ICVG, Dijon, France, 31 Aug-4 Sept 2009. Le Progrès Agricole et Viticole, pp 164-165

Frago E, Dicke M, Godfray HCJ (2012) Insect symbionts as hidden players in insect-plant interactions. Trends Ecol Evol 27:705-711. doi:10.1016/j.tree.2012.08.013

Frausin C (2000) Flavescenza dorata e legno nero della vite in FriuliVenezia Giulia. Inf Agrar 56:65-72

Galetto L, Marzachi C, Marques R, Graziano C, Bosco D (2011) Effects of temperature and $\mathrm{CO}_{2}$ on phytoplasma multiplication pattern in vector and plant. Bull Insectol 64:S151-S152

Garcia Salazar C, Whalon ME, Rahardja U (1991) Temperaturedependent pathogenicity of the X-disease mycoplasma-like organism to its vector, Paraphlepsius irroratus (Homoptera, Cicadellidae). Environ Entomol 20:179-184

Ge Q, Wen F (2006) Predicting the potential geographical distribution of flavescence doree and its vector Scaphoideus titanus Ball in China using DIVA-GIS. Acta Phytophylacica Sin 33:51-58

Gibson LP (1973) An annoted list of the Cicadellidae and Fulgoridae of Elm. USDA Forest Service Research Paper NE-278. Department of Agriculture, Forest Service, Northeastern Forest Experiment Station, Upper Darby

Granett J, Walker MA, Kocsis L, Omer AD (2001) Biology and management of grape phylloxera. Ann Rev Entomol 46:387-412. doi:10. 1146/annurev.ento.46.1.387

Gruber BR, Daugherty MP (2013) Understanding the effects of multiple sources of seasonality on the risk of pathogen spread to vineyards: vector pressure, natural infectivity, and host recovery. Plant Pathol 62:194-204. doi:10.1111/j.1365-3059.2012.02611.x

Gusberti M, Jermini M, Wyss E, Linder C (2008) Efficacité d'insecticides contre Scaphoideus titanus en vignobles biologiques et effets secondaires. Rev Suisse Vitic Arboric Hortic 40:173-177

Hamilton KGA (1983) Introduced and native leafhoppers common to the Old and New worlds (Rhynchota: Homoptera: Cicadellidae). Can Entomol 115:473-511. doi:10.4039/Ent115473-5

Hill GT, Sinclair WA (2000) Taxa of leafhoppers carrying phytoplasmas at sites of ash yellows occurrence in New York State. Plant Dis 84: 134-138. doi:10.1094/PDIS.2000.84.2.134

Hurd H (2003) Manipulation of medically important insect vectors by their parasites. Ann Rev Entomol 48:141-161. doi:10.1146/ annurev.ento.48.091801.112722

Jarausch W, Lansac M, Bliot C, Dosba F (1999) Phytoplasma transmission by in vitro graft inoculation as a basis for a preliminary screening method for resistance in fruit trees. Plant Pathol 48:283287. doi:10.1046/j.1365-3059.1999.00326.x

Jarausch W, Angelini E, Eveillard S, Malembic-Maher S (2013) Management of European fruit tree and grapevine phytoplasma diseases through genetic resistance. Phytopathogenic Mollicutes 3: 16-24. doi:10.5958/j.2249-4677.3.1.005

Jeger MJ, Holt J, Bosch FVD, Madden LV (2004) Epidemiology of insect-transmitted plant viruses: modelling disease dynamics and control interventions. Physiol Entomol 29:291-304. doi:10.1111/j. 0307-6962.2004.00394.x

Jermini M, Rossi A, Baillod M (1992) Study of trapping of the cicadellid Scaphoideus titanus Ball with the assistance of yellow traps. Rev Suisse Vitic Arboric Hortic 24:235-239

Jermini M, D'Adda G, Baumgartner J, Lozzia GC, Baillod M (1993) Nombre des pièges englués necessaires pour estimer la densité relative des populations de la cicadelle Scaphoideus titanus Ball en vignoble. Boll Zool Agrar Bachic 25:91-102

Jermini M, Gusberti M, Linder C, Marazzi C, Colombi L (2007) IPM and organic control strategies against Scaphoideus titanus in Switzerland. Paper presented at the European meeting of the IOBC/WPRS working group "Integrated Protection in Viticulture", Marsala (Italy), 25-27 October

Jonsson AM, Harding S, Krokene P, Lange H, Lindelow A, Okland B, Ravn HP, Schroeder LM (2011) Modelling the potential impact of global warming on Ips typographus voltinism and reproductive diapause. Clim Change 109:695-718. doi:10.1007/s10584-0110038-4

Krnjajic S, Mitrovic M, Cvrkovic T, Jovic J, Petrovic A, Forte V, Angelini E, Tosevski I (2007) Occurrence and distribution of Scaphoideus titanus in multiple outbreaks of "flavescence dorée" in Serbia. Bull Insectol 60:197-198

Kuszala C (1986) Influence du sexe et de l'âge des insectes vecteurs injectés dans l'épreuve d'infectivité des jaunisses des plantes. Mesure radiographique du volume injecté à Euscelidius variegatus (Kirschbaum). Agronomie 6:591-598. doi:10.1051/ agro: 19860612

Laimer M, Lemaire O, Herrbach E, Goldschmidt V, Minafra A, Bianco P, Wetzel $T$ (2009) Resistance to viruses, phytoplasmas and their vectors in the grapevine in Europe. J Plant Pathol 91:7-23. doi:10. 4454/jpp.v91i1.620

Laurent J, Agulhon R La flavescence dorée de la vigne. Situation et évolution de la maladie et de la cicadelle vectrice dans le vignoble français. In: Cavalloro R (ed) Plant-protection problems and prospects of integrated control in viticulture, Lisboa-Vila Real, 6-9 June 1989. International Organization for Biological and Integrated, Control, pp 489-496

LeCaherec F, Guillam MT, Beuron F, Cavalier A, Thomas D, Gouranton J, Hubert JF (1997) Aquaporin-related proteins in the filter chamber of homopteran insects. Cell Tissue Res 290:143-151. doi:10.1007/ s004410050916

Lee IM, Davis RE, Gundersen-Rindal DE (2000) Phytoplasma: phytopathogenic mollicutes. Annu Rev Microbiol 54:221-255. doi:10. 1146/annurev.micro.54.1.221 
Lefol C, Caudwell A, Lherminier J, Larrue J (1993) Attachment of the flavescence dorée pathogen (MLO) to leafhopper vectors and other insects. Ann Appl Biol 123:611-622. doi:10.1111/j.1744-7348. 1993.tb04931.x

Lefol C, Lherminier J, Boudon-Padieu E, Larrue J, Louis C, Caudwell A (1994) Propagation of flavescence dorée MLO (mycoplasma-like organism) in the leafhopper vector Euscelidius variegatus $\mathrm{Kbm}$. J Invertebr Pathol 63:285-293

Lemon SM, Sparling PF, Hamburg MA, Relman DA, Choffnes ER, Mack A (2008) Vector-borne diseases: understanding the environmental, human health, and ecological connections. Workshop summary. National Academies Press (US), Washington (DC)

Lessio F, Alma A (2004a) Dispersal patterns and chromatic response of Scaphoideus titanus ball (Homoptera Cicadellidae), vector of the phytoplasma agent of grapevine flavescence dorée. Agric For Entomol 6:121-127. doi:10.1111/j.1461-9563.2004.00212.x

Lessio F, Alma A (2004b) Seasonal and daily movement of Scaphoideus titanus ball (Homoptera: Cicadellidae). Environ Entomol 33:16891694. doi:10.1603/0046-225X-33.6.1689

Lessio F, Alma A (2006) Spatial distribution of nymphs of Scaphoideus titanus (Homoptera: Cicadellidae) in grapes, and evaluation of sequential sampling plans. J Econ Entomol 99:578-582. doi:10.1603/ 0022-0493-99.2.578

Lessio F, Tedeschi R, Alma A (2007) Presence of Scaphoideus titanus on American grapevine in woodlands, and infection with "flavescence dorée" phytoplasmas. Bull Insectol 60:373-374

Lessio F, Borgogno Mondino E, Alma A (2009b) Spatial correlation of Scaphoideus titanus Ball adults on European grapevine at a plot scale: a case study. In: Extended abstracts 16th Meeting of ICVG, Dijon, 31 Aug-4 Sept 2009. Le Progrès Agricole et Viticole, pp 166-167.

Lessio F, Tedeschi R, Pajoro M, Alma A (2009b) Seasonal progression of sex ratio and phytoplasma infection in Scaphoideus titanus Ball (Hemiptera: Cicadellidae). Bull Entomol Res 99:377-383. doi:10. 1017/S0007485308006457

Linder C, Jermini M (2007) Biologie et distribution du vecteur de la flavescence dorée dans les vignobles. Rev Suisse Vitic Arboric Hortic 97:97-101

Linder C, Schaub L, Klotzli-Estermann F (2010) Efficacité du traitement a l'eau chaude contre les oeufs de Scaphoideus titanus, vecteur de la flavescence dorée de la vigne. Rev Suisse Vitic Arboric Hortic 42: $132-135$

Logan JA, Regniere J, Powell JA (2003) Assessing the impacts of global warming on forest pest dynamics. Front Ecol Environ 1:130-137. doi: $10.2307 / 3867985$

Lucchi A, Mazzoni V, Presern J, Virant-Doberlet M (2004) Mating behaviour of Scaphoideus titanus Ball (Hemiptera: Cicadellidae). Paper presented at the 3rd European Hemiptera Congress, Saint Petersburg, Russia, 8-11 June

Madden LV, Nault LR (1983) Differential pathogenicity of corn stunting mollicutes to leafhopper vectors in Dalbulus and Baldulus species. Phytopathology 73:1608-1614. doi:10.1094/Phyto-73-1608

Maggi F, Marzachì C, Bosco D (2013) A stage-structured model of Scaphoideus titanus in vineyards. Environ Entomol 42:181-193. doi: $10.1603 / \mathrm{en} 12216$

Magud B, Tosevski I (2004) Scaphoideus titanus Ball. (Homoptera, Cicadellidae): a new pest in Serbia. Biljni Lekar (Plant Doctor) 32: 348-352

Maixner M Risks posed by the spread and dissemination of grapevine pathogens and their vectors. In: Alford DV, Backhaus GF (eds) Plant protection and plant health in Europe: introduction and spread of invasive species, Alton, UK, 9 June 2005. British Crop Protection Council, pp 141-146

Maixner M, Pearson RC, Boudon-Padieu E, Caudwell A (1993) Scaphoideus titanus, a possible vector of Grapevine Yellows in New York. Plant Dis 77:408-413. doi:10.1094/PD-77-0408
Maixner M, Reinert W, Darimont H (2000) Transmission of grapevine yellows by Oncopsis alni (Schrank) (Auchenorrhyncha : Macropsinae). Vitis 39:83-84

Malagnini V, Pedrazzoli F, Gualandri V, Forno F, Zasso R, Pozzebon A, Ioriatti C (2010) A study of the effects of 'Candidatus Phytoplasma mali' on the psyllid Cacopsylla melanoneura (Hemiptera: Psyllidae). J Invertebr Pathol 103:65-67. doi:10.1016/j.jip.2009.11.005

Malausa JC, Sentenac G (2011) Parasitoïdes de Scaphoideus titanus. In: Sentenac G (ed) La faune Auxiliaire des vignobles de France. France Agricole, Paris, pp 143-146

Malausa JC, Nusillard B, Giuge L (2003) Lutte biologique contre la cicadelle vectrice de la flavescence dorée. Phytoma 565:24-27

Malembic-Maher S, Le Gall F, Danet JL, de Borne FD, Bove JM, Garnier-Semancik M (2005) Transformation of tobacco plants for single-chain antibody expression via apoplastic and symplasmic routes, and analysis of their susceptibility to stolbur phytoplasma infection. Plant Sci 168:349-358. doi:10.1016/j.plantsci.2004.08.008

Mannini F (2007) Hot water treatment and field coverage of mother plant vineyards to prevent propagation material from phytoplasma infections. Bull Insectol 60:311-312

Maramorosch K, Jensen DD (1963) Harmful and beneficial effects of plant viruses in insects. Annu Rev Microbiol 17:495-530. doi:10. 1146/annurev.mi.17.100163.002431

Marchesini E, Monta LD (1994) Observations on natural enemies of Lobesia botrana (Den. \& Schiff.) (Lepidoptera, Tortricidae) in Venetian vineyards. Boll Zool Agrar Bachic 26:201-230

Marko V, Blommers LHM, Bogya S, Helsen H (2008) Kaolin particle films suppress many apple pests, disrupt natural enemies and promote woolly apple aphid. J Appl Entomol 132:26-35. doi:10.1111/j. 1439-0418.2007.01233.x

Marzorati M, Alma A, Sacchi L, Pajoro M, Palermo S, Brusetti L, Raddadi N, Balloi A, Tedeschi R, Clementi E, Corona S, Quaglino F, Bianco PA, Beninati T, Bandi C, Daffonchio D (2006) A novel bacteroidetes symbiont is localized in Scaphoideus titanus, the insect vector of flavescence dorée in Vitis vinifera. Appl Environ Microbiol 72:1467-1475. doi:10.1128/AEM.72.2.1467-1475.2006

Maw HEL, Foottit RG, Hamilton KGA, Scudder GGE (2000) Checklist of the Hemiptera of Canada and Alaska. NRC Research Press, Ottawa

Mayer CJ, Vilcinskas A, Gross J (2008) Pathogen-induced release of plant allomone manipulates vector insect behavior. J Chem Ecol 34: 1518-1522. doi:10.1007/s10886-008-9564-6

Mazzoni V, Ioriatti C, Trona F, Lucchi A, De Cristofaro A, Anfora G (2009a) Study on the role of olfaction in host plant detection of Scaphoideus titanus (Hemiptera: Cicadellidae) nymphs. J Econ Entomol 102:974-980. doi:10.1603/029.102.0316

Mazzoni V, Lucchi A, Cokl A, Presern J, Virant-Doberlet M (2009b) Disruption of the reproductive behaviour of Scaphoideus titanus by playback of vibrational signals. Entomol Exp Appl 133:174-185. doi:10.1111/j.1570-7458.2009.00911.x

Mazzoni V, Prešern J, Lucchi A, Virant-Doberlet M (2009c) Reproductive strategy of the Nearctic leafhopper Scaphoideus titanus Ball (Hemiptera: Cicadellidae). Bull Entomol Res 99:401413. doi:10.1017/S0007485308006408

Mazzoni V, Trona F, Ioriatti C, Lucchi A, Eriksson A, Anfora G (2011) Attractiveness of different colours to Scaphoideus titanus Ball (Hemiptera: Cicadellidae) adults. IOBC/WPRS Bull 67:281-284

Metcalf ZP (1967) General catalogue of the Homoptera. Fascicle VI. Cicadelloidea. Part 10. Section III. Euscelidae. U.S. Department of Agriculture, Agriculture Research Service, Washington (DC)

Morone C, Boveri M, Giosue S, Gotta P, Rossi V, Scapin I, Marzachi C (2007) Epidemiology of flavescence dorée in vineyards in northwestern Italy. Phytopathology 97:1422-1427. doi:10.1094/ PHYTO-97-11-1422

Moutous G, Hevin M (1986) Transmission expérimentale de la maladie de l'écorce liégeuse de la vigne, "corky-bark", par la cicadelle 
Scaphoideus littoralis Ball. (Homoptera Jassidae). Agronomie 6: 387-392. doi:10.1051/agro:19860409

Nakamura Y, Yukuhiro F, Matsumura M, Noda H (2012) Cytoplasmic incompatibility involving Cardinium and Wolbachia in the whitebacked planthopper Sogatella furcifera (Hemiptera: Delphacidae). Appl Entomol Zool 47:273-283. doi:10.1007/s13355-012-0120-Z

Namba S, Boscia D, Azzam O, Maixner M, Hu JS, Golino D, Gonsalves D (1991) Purification and properties of closterovirus-like particles associated with grapevine corky bark disease. Phytopathology 81 : 964-970. doi:10.1094/Phyto-81-964

OFAG (2013) Index des produits phytosanitaires. Office fédéral de l'agriculture. http://www.blw.admin.ch/psm/schaderreger/index. html?lang=fr\&item=11158. Accessed 04 April 2013

Oliver KM, Degnan PH, Burke GR, Moran NA (2010) Facultative symbionts in aphids and the horizontal transfer of ecologically important traits. Ann Rev Entomol 55:247-266. doi:10.1146/ annurev-ento-112408-085305

Olivier CY, Lowery DT, Stobbs LW, Vincent C, Saguez J, Galka B, Bittner LA, Whybourne KJ (2008) Phytoplasma diseases in Canadian vineyards. Paper presented at the 1st International ENDURE Conference, La Grande Motte, France, 12-15 October

Orosz S, Zsolnai B (2010) Survey of the presence of Scaphoideus titanus Ball in Hungary. Acta Phytopathol Entomol Hung 45:115-119. doi: 10.1556/APhyt.45.2010.1.9

Osborn H, Knull DJ (1946) Check list oh Ohio leafhopper (Homoptera: Cicadellidae). Ohio J Sci 46:329-336

Osler R, Fortusini A, Belli G (1975) Presenza di Scaphoideus littoralis in vigneti dell'Oltrepò pavese affetti da una malattia tipo "Flavescence dorée". Inf Fitopatol 25:13-15

Papura D, van Helden M, Giresse X, Salar P, Danet JL, Foissac X, Malembic-Maher S (2007) Genetic structure of Scaphoideus titanus populations and genetic diversity of the epidemic strains of "flavescence dorée" phytoplasma: the situation in France. Bull Insectol 60:333-334

Papura D, Delmotte F, Giresse X, Salar P, Danet JL, van Helden M, Foissac X, Malembic-Maher S (2009) Comparing the spatial genetic structures of the Flavescence doree phytoplasma and its leafhopper vector Scaphoideus titanus. Infect Genet Evol 9:867-876. doi:10. 1016/j.meegid.2009.05.009

Papura D, Burban C, van Helden M, Giresse X, Nusillard B, Guillemaud T, Kerdelhué C (2012) Microsatellite and mitochondrial data provide evidence for a single major introduction for the Neartic leafhopper Scaphoideus titanus in Europe. PLoS ONE 7:e36882. doi: 10.1371/journal.pone.0036882

Pavan F, Villani A, Fornasier F, Girolami V (1997) Ruolo del vivaismo nella diffusione della flavescenza dorata. Inf Agrar 53:69-71

Pavan F, Mori N, Bressan S, Mutton P (2012) Control strategies for grapevine phytoplasma diseases: factors influencing the profitability of replacing symptomatic plants. Phytopathol Mediterr 51:11-22

Posenato G, Mori N, Bressan A, Girolami V, Sancassani GP (2001) Scaphoideus titanus, vettore della flavescenza dorata: conoscerlo per combatterlo. Inf Agrar 57:91-93

Pueyo C, Carrara J, Parent E (2008) Flavescence dorée en LanguedocRoussillon: bilan de 10 années de lutte (synthèse des données 19972007). Direction Régionale de l'Agriculture et de la Forêt Languedoc-Roussillon, Service Régional de la Protection des Végétaux, Montpellier

Purcell AH (1982) Insect vector relationships with procaryotic plant pathogens. Annu Rev Phytopathol 20:397-417. doi:10.1146/ annurev.py.20.090182.002145

Purcell AH (1988) Increased survival of Dalbulus maidis, a specialist on maize, on non-host plants infected with mollicute plant pathogens. Entomol Exp Appl 46:187-196. doi:10.1111/j.1570-7458.1988. tb01110.x
Quaglino F, Zhao Y, Casati P, Bulgari D, Bianco PA, Wei W, Davis RE (2013) 'Candidatus Phytoplasma solani', a novel taxon associated with stolbur and bois noir related diseases of plants. Int J Syst Evol Microbiol. doi:10.1099/ijs.0.044750-0

Quartau JA, Guimarães JM, André G (2001) On the occurrence in Portugal of the nearctic Scaphoideus titanus Ball (Homoptera, Cicadellidae), the natural vector of the grapevine "flavescence dorée" (FD). IOBC/WPRS Bull 24:273-276

Rahola J, Reyes J, Giralt L, Torres E, Barrios G (1997) La flavescencia dorada en los vinedos del Alt Emporda (Girona). Bol Sanid Veg Plagas 23:403-416

Ribaut H (1952) Homoptères Auchenorhynques II (Jassidae), vol 57. Faune de France. Fédération Française des Sciences Naturelles, Paris

Riehle MA, Jacobs-Lorena M (2005) Using bacteria to express and display anti-parasite molecules in mosquitoes: current and future strategies. Insect Biochem Mol Biol 35:699-707. doi:10.1016/j. ibmb.2005.02.008

Rigamonti IE, Jermini M, Fuog D, Baumgartner J (2011) Towards an improved understanding of the dynamics of vineyard-infesting Scaphoideus titanus leafhopper populations for better timing of management activities. Pest Manag Sci 67:1222-1229. doi:10.1002/ps.2171

Rigamonti I, Trivellone V, Brambilla C, Jermini M, Baumgartner J (2013a) Research and management oriented sampling plans for vine inhabiting Scaphoideus titanus grape leafhopper nymphs. IOBC/WPRS Bull 85:29-35

Rigamonti I, Trivellone V, Jermini M, Baumgartner J (2013b) Multiannual infestation patterns of grapevine canopy inhabiting Scaphoideus titanus Ball leafhoppers. IOBC/WPRS Bull 85:43-48

Sacchi L, Genchi M, Clementi E, Bighardi E, Avanzati AM, Pajoro M, Negri I, Marzorati M, Gonella E, Alma A, Daffonchio D, Bandi C (2008) Multiple symbiosis in the leafhopper Scaphoideus titanus (Hemiptera: Cicadellidae): details of transovarial transmission of Cardinium $s p$ and yeast-like endosymbionts. Tissue Cell 40:231242. doi:10.1016/j.tice.2007.12.005

Santinelli C, Santoni M, Braccini P, Botti S, Bertaccini A (2003) Trovato in Umbria Scaphoideus titanus, vettore della flavescenza dorata. Inf Agrar 59:81-82

Santini L, Lucchi A (1998) Presenza in Toscana del cicadellide Scaphoideus titanus. Inf Agrar 54:73-74

Schaerer S, Johnston H, Gugerli P, Linder C, Shaub L, Colombi L (2007) "Flavescence dorée" in Switzerland: spread of the disease in canton of Ticino and of its insect vector, now also in cantons of Vaud and Geneva. Bull Insectol 60:375-376

Schraiber JG, Kaczmarczyk AN, Kwok R, Park M, Silverstein R, Rutaganira FU, Aggarwal T, Schwemmer MA, Hom CL, Grosberg RK, Schreiber SJ (2012) Constraints on the use of lifespan-shortening Wolbachia to control dengue fever. J Theor Biol 297:26-32. doi:10.1016/j.jtbi.2011.12.006

Schvester D (1962) Sur les causes de la propagation en Armagnac et en Chalosse de la Flavescence dorée de la vigne. Rev Zool Agr 10-12: 132-135

Schvester D (1969) Traitements insecticides et guérison des vignes atteintes de Flavescence dorée. Ann Zool Ecol Anim 1:467-494

Schvester D, Carle P, Moutous G (1961) Sur la transmission de la Flavescence dorée des vignes par une cicadelle. C R Acad Agric Fr 47:1021-1024

Schvester D, Moutous G, Bonfils J, Carle P (1962a) Étude biologique des cicadelles de la vigne dans le Sud-Ouest de la France. Ann Epiphyt 13:205-237

Schvester D, Moutous G, Carle P (1962b) Scaphoideus littoralis Ball. (Homopt. Jassidae) cicadelle vectrice de la Flavescence dorée de la vigne. Rev Zool Agr Appl 10-12:118-131

Schvester D, Carle A, Moutous G (1969) Nouvelles données sur la transmission de la Flavescence dorée de la vigne par Scaphoideus littoralis Ball. Ann Zool Ecol Anim 1:445-465 
Seljak G (1987) Scaphoideus titanus Ball (= Sc. littoralis Ball), novi stetnik vinove loze u Jugoslaviji. Zast Bilja 38:349-357

Seljak G (2008) Distribution of Scaphoideus titanus in Slovenia: its new significance after the first occurrence of grapevine "flavescence doree". Bull Insectol 61:201-202

Sharon R, Soroker V, Wesley SD, Zahavi T, Harari A, Weintraub PG (2005) Vitex agnus-castus is a preferred host plant for Hyalesthes obsoletus. J Chem Ecol 31:1051-1063. doi:10.1007/s10886-0054247-z

Sinclair WA, Townsend AM, Griffiths HM, Whitlow TH (2000) Responses of six Eurasian Ulmus cultivars to a North American elm yellows phytoplasma. Plant Dis 84:1266-1270. doi:10.1094/ PDIS.2000.84.12.1266

Sisterson MS (2009) Transmission of insect-vectored pathogens: effects of vector fitness as a function of infectivity status. Environ Entomol 38:345-355. doi:10.1603/022.038.0206

Sivčev BV, Sivčev IL, Vasic ZZR (2010) Plant protection products in organic grapevine growing. J Agric Sci Belgrade 55:103-122. doi: 10.2298/jas1001103s

Stacconi MVR, Romani R (2012) Antennal sensory structures in Scaphoideus titanus Ball (Hemiptera: Cicadellidae). Microsc Res Tech 75:458-466. doi:10.1002/jemt.21078

Stadler B, Dixon AFG (2005) Ecology and evolution of aphid-ant interactions. Annu Rev Ecol Evol Syst 36:345-372. doi:10.1146/ annurev.ecolsys.36.091704.175531

Steffek R, Reisenzein H, Zeisner N (2007) Analysis of the pest risk from Grapevine flavescence dorée phytoplasma to Austrian viticulture. EPPO Bull 37:191-203. doi:10.1111/j. 1365-2338.2007.01102.x

Stoeckli S, Hirschi M, Spirig C, Calanca P, Rotach MW, Samietz J (2012) Impact of climate change on voltinism and prospective diapause induction of a global pest insect-Cydia pomonella (L.). PLoS ONE $7: \mathrm{e} 35723$

Strauss E (2009) Phytoplasma research begins to bloom. Science 325: 388-390. doi:10.1126/science.325 388

Sugio A, Kingdom HN, MacLean AM, Grieve VM, Hogenhout SA (2011) Phytoplasma protein effector SAP11 enhances insect vector reproduction by manipulating plant development and defense hormone biosynthesis. Proc Natl Acad Sci U S A 108:E1254-E1263. doi:10.1073/pnas.1105664108

Taylor LR (1974) Insect migration, flight periodicity and the boundary layer. J Anim Ecol 43:225-238

Thiéry D, Xuéreb A, Villemant C, Sentenac G, Delbac L, Kuntzman P (2001) The parasites of grape tortricids: noticed on several species present in 3 French vine regions. IOBC/WPRS Bull 24: 135-141

Trespaille-Barrau JM, Grosman J (2011) Groupe de travail national flavescence dorée. Communications et relevé de décisions. Lisle sur Tarn
Trivellone V, Jermini M, Linder C, Cara C, Delabays N, Baumgartner J (2013) Role de la flore du vignoble sur la distribution de Scaphoideus titanus. Rev Suisse Vitic Arboric Hortic 45:222-228

Trombulak SC, Frissell CA (2000) Review of ecological effects of roads on terrestrial and aquatic communities. Conserv Biol 14:18-30. doi: 10.1046/j.1523-1739.2000.99084.x

Tubajika KM, Civerolo EL, Puterka GJ, Hashim JM, Luvisi DA (2007) The effects of kaolin, harpin, and imidacloprid on development of Pierce's disease in grape. Crop Prot 26:92-99. doi:10.1016/j.cropro. 2006.04.006

Välimäki P, Kivelä SM, JääskeläInen L, Kaitala A, Kaitala V, Oksanen J (2008) Divergent timing of egg-laying may maintain life history polymorphism in potentially multivoltine insects in seasonal environments. J Evol Biol 21:1711-1723. doi:10.1111/j.1420-9101. 2008.01597.x

Välimäki P, Kivelä SM, Mäenpää MI, Tammaru T (2013) Latitudinal clines in alternative life histories in a geometrid moth. J Evol Biol 26:118-129. doi:10.1111/jeb.12033

van Helden M, Fulchin E, Verpy A, Gil F, Garcia C (2011) Adult monitoring improves control of the flavescence doree leafhopper Scaphoideus titanus in Gironde (France) while using less pesticide! IOBC/WPRS Bull 67:9-16

Vidano C (1964) Scoperta in Italia dello Scaphoideus littoralis Ball cicalina americana collegata alla "Flavescence dorée" della Vite. Ital Agric 101:1031-1049

Vidano C (1966) Scoperta della ecologia ampelofila del Cicadellide Scaphoideus littoralis Ball nella regione neartica originaria. Ann Fac Sci Agrar Univ Stud Torino 3:297-302

Vidano C, Arzone A, Alma A, Arnò C (1988) Flavescenza dorata della vite e Auchenorrinchi probabili vettori del suo agente patogeno in Piemonte. Ann Fac Sci Agrar Univ Stud Torino 15:29-37

Viggiani G (2002) Il vettore della flavescenza trovato in Basilicata. Inf Agrar 58:59

Weintraub PG, Beanland L (2006) Insect vectors of phytoplasmas. Ann Rev Entomol 51:91-111. doi:10.1146/annurev.ento.51.110104. 151039

Wu D, Daugherty SC, Van Aken SE, Pai GH, Watkins KL, Khouri H, Tallon LJ, Zaborsky JM, Dunbar HE, Tran PL, Moran NA, Eisen JA (2006) Metabolic complementarity and genomics of the dual bacterial symbiosis of sharpshooters. PLoS Biol 4:1079-1092. doi:10. 1371/journal.pbio.0040188

Xuéreb A, Thiery D (2006) Does natural larval parasitism of Lobesia botrana (Lepidoptera: Tortricidae) vary between years, generation, density of the host and vine cultivar? Bull Entomol Res 96:105-110. doi:10.1079/ber2005393

Zahavi T, Peles S, Harari AR, Soroker V, Sharon R (2007) Push and pull strategy to reduce Hyalesthes obsoletus population in vineyards by Vitex agnus castus as trap plant. Bull Insectol $60: 297-298$ 